\title{
Preparation of Nanomaterial Wettable Powder Formulations of Antagonistic Bacteria from Phellodendron chinense and the Biological Control of Brown Leaf Spot Disease
}

\author{
Yanling Zeng ${ }^{1}$, Han Liu' ${ }^{2}$, Tianhui Zhu', Shan Han ${ }^{1}$, and Shujiang Li $\mathbb{B}^{1,3 *}$ \\ ${ }^{1}$ College of Forestry, Sichuan Agricultural University, Chengdu 611130, China \\ ${ }^{2}$ Ganzi Institute of Forestry Research, Kangding 626001, China \\ ${ }^{3}$ Key Laboratory of National Forestry \& Grassland Administration on Forest Resources Conservation and Ecologi- \\ cal Safety in the Upper Reaches of the Yangtze River, College of Forestry, Sichuan Agricultural University, Chengdu \\ 611130, China
}

(Received on February 8, 2021; Revised on March 15, 2021; Accepted on March 22, 2021)

Brown leaf spot disease caused by Nigrospora guilinensis on Phellodendron chinense occurs in a large area in Dayi County, Chengdu City, Sichuan Province, China each year. This outbreak has severely reduced the production of Chinese medicinal plants $P$. chinense and caused substantial economic losses. The bacterial isolate JKB05 was isolated from the healthy leaves of $P$. chinense, exhibited antagonistic effects against $N$. guilinensis and was identified as Bacillus megaterium. The following fermentation medium and conditions improved the inhibitory effect of $B$. megaterium $\mathrm{JKB} 05$ on $N$. guilinensis: $2 \%$ glucose, $0.1 \%$ soybean powder, $0.1 \% \mathrm{KCl}$, and $0.05 \% \mathrm{MgSO}_{4}$; initial concentration $6 \times 10^{6} \mathrm{cfu} / \mathrm{ml}$, and a 42-h optimal fermentation time. A composite of $0.1 \%$ nano- $\mathrm{SiO}_{2} \mathrm{JKB05}$ improved the thermal stability, acid-base stability and ultraviolet resistance by $16 \%, 12 \%$, and $38.9 \%$, respectively, and nano- $\mathrm{SiO}_{2}$ was added to the fermentation process. The best formula for the wettable powder was $35 \%$ kaolin,

\section{*Corresponding author.}

Phone) +86-186-0835-7494, FAX) +86-028-86291456

E-mail) lishujiangsumer@163.com

ORCID

Shujiang Li

https://orcid.org/0000-0003-3328-5332

Handling Editor : Kihyuck Choi

(c) This is an Open Access article distributed under the terms of the Creative Commons Attribution Non-Commercial License (http:// creativecommons.org/licenses/by-nc/4.0) which permits unrestricted noncommercial use, distribution, and reproduction in any medium, provided the original work is properly cited.

Articles can be freely viewed online at www.ppjonline.org.
$4 \%$ polyethylene glycol, $8 \%$ Tween, and $2 \%$ humic acid. The following quality test results for the wettable powder were obtained: wetting time $87.0 \mathrm{~s}$, suspension rate $80.33 \%$, frequency of microbial contamination $0.08 \%$, pH 7.2, fineness $95.8 \%$, drying loss $1.47 \%$, and storage stability $\geq 83.5 \%$. A pot experiment revealed that the ability of JKB05 to prevent fungal infections on $P$. chinense increased considerably and achieved levels of control as high as $94 \%$. The use of nanomaterials significantly improved the ability of biocontrol bacteria to control this disease.

Keywords : Bacillus megaterium, biological control, nanomaterials, Nigrospora guilinensis, Phellodendron chinense

Phellodendron chinense Schneid, a traditional Chinese medicinal plant, is widely planted in Sichuan Province, China, owing to its high medicinal value. Zeng et al. (2020) found that brown leaf spot disease caused by Nigrospora guilinensis on $P$. chinense occurred in a large area in Dayi County, Chengdu City, Sichuan Province, and severely reduced the production of $P$. chinense causing economic losses. However, the control of brown leaf spot disease on $P$. chinense had not yet been reported. Bacillus sp. has become the most widely used and potential biological control resource (Oslizlo et al., 2015), and much success has been achieved in the use of Bacillus to control plant diseases. It is generally believed that the biocontrol mechanisms of Bacillus mainly include nutrition and space site competition (Bacon et al., 2001; Zeriouh et al., 2014), secretion of antimicrobial substances (Hiradate et al., 2002; Johnson 
and Campbell, 1945; Liu et al., 2007), and induction of plant disease resistance (Niu et al., 2011; Van der Ent et al., 2009). However, the registration, production, and use of Bacillus sp. still proceeds very slowly (Zaki et al., 2020). The reasons are that biopesticides have a weaker immediate impact than chemical pesticides (Hunter, 2009). Compared with chemical pesticides, the production cycle of biopesticides is longer; the investment is relatively greater, and application in the field is affected by the soil microbial community, soil properties, temperature and humidity, $\mathrm{pH}$ and other environmental factors, resulting in unstable control effects (Gangireddygari et al., 2017). Species of Bacillus are often used for the biocontrol of various plant pathogens, but the ability of Bacillus to control diseases is typically unstable in field experiments (Setlow et al., 2006). Moreover, biological control has been controversial for a long time given the lack of evidence that these microbial agents have almost no harmful effects, such as affecting soil microbial diversity and inhibiting normal growth of plants (Shadduck, 1983). It is difficult to produce qualitative changes based on the production and application of biopesticides, and a large gap exists compared with chemical pesticides. Nanotechnology is expected to thoroughly affect the way in which science addresses medicine, food, electronics, and the environment (Lim, 2004). The application of nanoparticles (NPs) and technologies in the field of pesticides may change the physical and chemical properties of pesticides, rendering them highly dispersible or easily suspended in water, improving their rate of utilization, and reducing the amount of pesticide residues and environmental pollution (Camara et al., 2019). NPs may act upon plant pathogens at a much lower dose with much greater efficiency compared with conventional pesticides, and considerable work has been conducted to test the effects of NPs on plant pathogenic fungi (Khan et al., 2019). Kim et al. (2012) analyzed the inhibitory effect of three different Ag NPs against various plant pathogenic fungi, including Alternaria alternata, A. brassicicola, Botrytis cinerea, Cladosporium cucumerinum, Corynespora cassiicola, Cylindrocarpon destructans, Didymella bryoniae, Fusarium oxysporum f. sp. cucumerinum, $F$. oxysporum f. sp. lycopersici, F. oxysporum, $F$. solani, Glomerella cingulata, Monosporascus cannonballus, and Stemphylium lycopersici and the oomycetes Pythium aphanidermatum and $P$. spinosum in vitro. The Ag NPs mixed with polyvinylpyrrolidone were tested for fungicidal activity against different yeasts and molds, such as Candida albicans, C. krusei, C. tropicalis, C. glabrata, and Aspergillus brasiliensis. The hybrid materials showed strong antifungal effects against these microbes (Bryaskova et al., 2011). ZnO NPs have been reported to significantly inhibit the growth of $B$. cinerea and Penicillium expansum at $3 \mathrm{mmol} / \mathrm{l}$. Scanning electron microscopy images and Raman spectra indicated that $\mathrm{ZnO}$ NPs caused the deformation of fungal hyphae and prevented the development of conidiophores and conidia (He et al., 2011). In addition, the effective use of silica-silver NPs against $B$. cinerea, Rhizoctonia solani and Colletotrichum gloeosporioides has been reported (Park et al., 2006). The effects of NPs on bacteria have largely been examined on human pathogens, whereas plant pathogens have been rarely studied (Khan and Rizvi, 2014). One exception as a study in which nano copper was reported to effectively control Xanthomonas axonopodis pv. punicae, which causes blight in pomegranate (Mondal and Mani, 2012). The compound inhibited the growth of bacterium at $0.2 \mathrm{ppm}$, which is a concentration $>10,000$ times lower than that usually recommended for $\mathrm{Cu}$-oxychloride. Similarly, Azam et al. (2012) reported the suppressive effect of $\mathrm{CuO}$ NPs on the human pathogens Staphylococcus aureus, Bacillus subtilis, Pseudomonas aeruginosa, and Escherichia coli. Nanosized silica-silver inhibited plant pathogenic bacteria, and 100 ppm of nanosized silica silver completely inhibited colonization by the bacteria (Park et al., 2006). Several fertilizer manufacturing companies are formulating nano emulsions and waterbased or oil-based suspensions of nanoscale particles (Khan et al., 2016). However, some researchers believe that the large use of nanomaterials and industrial consumption will add to the levels of environmental pollution. Therefore, the positive and negative effects of these NPs on agriculture and the environment should be ascertained before their commercial use in plant disease management in the field (Ali et al., 2020). Recently, the integration of nanotechnology and agricultural biotechnology has gradually become a powerful tool for the efficient production and sustainable development of modern agriculture (Sekhon, 2014). Nano emulsions can serve as better pesticide delivery systems owing to their enhanced kinetic stability, smaller size, low viscosity, and optical transparency (de Campos et al., 2012). The use of micro or nano emulsions as a carrier for pesticide delivery can improve the solubility and bioavailability of the active ingredients of the pesticides. The objective of this study was to isolate biocontrol strains from healthy $P$. chinense leaves and prepare biocontrol agents combined with nanomaterials to control brown leaf spot disease in P. chinense.

\section{Materials and Methods}

Plant samples and disease fungus. $N$. guilinensis strain PHC1904 (internal transcribed spacer: GenBank acces- 
sion MN326528; EF1- $\alpha$ : MN400073; TUB: MN400072) was purified and screened by conventional tissue isolation and single spore purification from diseased leaves of $P$. chinense in Dayi County, located at $30^{\circ} 37^{\prime} 06.9 \mathrm{~N}$, $103^{\circ} 19^{\prime} 18.3$ E, altitude 1,260 m, Chengdu City, Sichuan Province, China. Two-year-old healthy $P$. chinensis plants (50-70 $\mathrm{cm}$ high) were collected from a plantation in Dayi County and planted in the greenhouse at Sichuan Agricultural University, Chengdu, China.

Culture medium. Nutrient agar (NA) was prepared using $3.0 \mathrm{~g}$ beef extract, $10.0 \mathrm{~g}$ peptone, $5.0 \mathrm{~g}$ sodium chloride, $20.0 \mathrm{~g}$ agar powder, and 1,000 $\mathrm{ml}$ of distilled water $(\mathrm{pH} 7.0)$. Nutrient broth was prepared using $3.0 \mathrm{~g}$ beef extract, 10.0 g peptone, $5.0 \mathrm{~g}$ sodium chloride, and 1,000 $\mathrm{ml}$ of distilled water ( $\mathrm{pH}$ 7.0). Potato dextrose agar (PDA) medium was prepared using $200 \mathrm{~g}$ potato (boiled and filtered to obtain the filtrate), $20.0 \mathrm{~g}$ glucose, $15.0 \mathrm{~g}$ agar powder, and 1,000 $\mathrm{ml}$ distilled water. Potato dextrose broth was prepared using $200 \mathrm{~g}$ potato (boiled and filtered to obtain the filtrate), $20.0 \mathrm{~g}$ glucose, and $1,000 \mathrm{ml}$ distilled water.

Isolation and purification of biocontrol bacteria. The interaction between endophytes and plant cells is more stable than those of rhizosphere microorganisms (Brader et al., 2017). Healthy leaves of 2 -year-old potted $P$. chinense were collected, and the surface of healthy leaves was thoroughly disinfected (soaked in 75\% alcohol for 1-2 min and then disinfected with 1-3\% sodium hypochlorite solution for 3-5 $\mathrm{min}$ ), ground in a sterilized mortar, added to an appropriate amount of sterile water, ground evenly, and isolated from the leaves using dilution separation method (Slama et al., 2019). Based on the morphological characteristics of the colony, different bacterial strains were selected and purified by repeated streaking on the same medium. Single colonies were selected using an aseptic inoculation ring and cultured on NA solid medium at $30^{\circ} \mathrm{C}$ for $48 \mathrm{~h}$. The purified strains were frozen a glycerol stock at $4^{\circ} \mathrm{C}$.

Screening the antagonistic bacteria. The preliminary screening method was a PDA confrontation test (Boukaew et al., 2017). $N$. guilinensis was placed on one side of the PDA media, and the biocontrol bacterial samples were cultured $3 \mathrm{~cm}$ away from $N$. guilinensis on the other side of the PDA culture medium. The blank control was set as follows: only $N$. guilinensis was inoculated in PDA media and cultured $25^{\circ} \mathrm{C}$ for 7 days. The presence of a bacteriostatic zone was observed and recorded, and the width of the bacteriostatic zone (the distance between the center of the bacterial colony and the edge of $N$. guilinensis) in the culture medium was measured using a digital caliper. The strains with obvious antibacterial band widths and antibacterial effects were preliminarily screened. The growth rate method was used to obtain the most effective and stable biocontrol strains (Mi et al., 2018).

Identification of the antagonistic bacteria. Morphological identification, the analyses of physiological and biochemical characteristics and molecular biological identification were performed. Colony morphology was assessed based on the size and regularity of the colony surface. Physiological characteristics were identified based on Gram staining (Claus, 1992). Gram staining was performed (G+: purple; G-: red) using the manufacturer's instructions for a Gram staining kit (G1060, Solarbio Science \& Technology Co. Ltd., Beijing, China). After the Gram staining, the smears were stained with a $5 \%$ solution of malachite green for 10 min and washed with water. The samples were then stained with a $0.5 \%$ solution of saffron for $30 \mathrm{~s}$ and washed and dried for microscopic examination to determine the cellular morphology, form and position of spores and the swelling of the sporangia. A solution of $3 \% \mathrm{H}_{2} \mathrm{O}_{2}$ that contained the strain was added to a slide to test for catalase (Thomas et al., 2006), and the presence of bubbles was observed. The test was positive if bubbles were observed, while it was negative if there were no bubbles. Casein, gelatin and starch hydrolysis was determined as described by (Smibert and Krieg, 1994). The bacteria were grown in an anaerobic chamber that was filled with a mixed gas (nitrogen, 90\%; hydrogen, $5 \%$; carbon dioxide, $5 \%$ ) to measure anaerobic growth. To verify whether the cells are capable of using citrate as a carbon source (Cromwick and Gross, 1995), the activity of lecithinase was determined on plate count agar that contained egg yolk (Gray et al., 2005).

The 16S rRNA, DNA gyrase subunit A (gyrA), and $D N A$ gyrase subunit $B$ (gyr $B$ ) genes were combined for a sequence alignment, and a phylogenetic tree was constructed to determine the species of the strain. 16S rRNA from the strain was amplified using a 27F (5'-AGAGTTTGATCCTGGCTCAG-3') and 1492R (5'-GGTTACCTTGTTACGACTT-3') primer set (Chun and Bae, 2000). gyrA from the strain was amplified using the gyrA-F (5'-CAGTCAGGAAATGCGTACGTCCTT-3') and gyrAR (5'-CAAGGTAATGCTCCAGGCATTGCT-3') primer set (Flanagan et al., 2007), while gyrB from the strain was amplified using the UP1f (5'-GAAGTCATCATGACCGTTCTGCAYGCNGGNGGNAARTTYGA-3') and UP2r (5'-AGCAGGGTACGGATGTGCGAGCCRTCNACRTCNGCRTCNGTCAT-3') primer set (Yamamoto and Harayama, 1995). The PCR conditions were $94^{\circ} \mathrm{C}$ for 
$5 \mathrm{~min}$, followed by 40 cycles at $94^{\circ} \mathrm{C}$ for $30 \mathrm{~s}, 50^{\circ} \mathrm{C}$ (for 16S rRNA and $g y r A$ ), or $62^{\circ} \mathrm{C}$ (for $g y r B$ ) for $1 \mathrm{~min}, 72^{\circ} \mathrm{C}$ for $2 \mathrm{~min}$, and a final elongation at $72^{\circ} \mathrm{C}$ (for $16 \mathrm{~S}$ rRNA and $g y r B$ ) or $68^{\circ} \mathrm{C}$ (for $g y r A$ ) for $10 \mathrm{~min}$. The sequencing results of PCR products were compared and analyzed in the ezbiocloud (https://www.ezbiocloud.net/) and NCBI databases (https://www.ncbi.nlm.nih.gov/), and sequences with a high similarity of related genes were downloaded. The phylogenetic trees of the 16S rRNA, gyrA, and gyrB gene sequences were constructed by the neighbor-joining method using MEGA software version 5.1. The number of repeats of the bootstrap test was set to 1,000 , which confirmed the phylogenetic status of the biocontrol strain.

Detection of growth and bacteriostatic effects. The bacterial density $\left(\mathrm{OD}_{600}\right)$ was used to monitor the growth of bacteria. The fermentation broth of biocontrol was collected, and sterile liquid medium was used as the control. The absorbance at $600 \mathrm{~nm}$ was measured (Storek et al., 2019), and the growth of biocontrol bacteria was recorded. The Oxford cup method was used determine the bacteriostatic effects (He et al., 2018). The Oxford cup was placed in a sterile PDA dish prepared in advance. The Oxford cup was $7 \mathrm{~mm}$ in diameter, and $120 \mu \mathrm{l}$ samples were added to it using an adjustable pipette. $N$. guilinensis was inoculated in the center of the plate. The control group was treated with sterile water and cultured at $25^{\circ} \mathrm{C}$ until the mycelia of the control group were full of culture medium. The experiment was conducted in triplicate.

$$
\text { Inhibition rate }(\%)=\frac{\begin{array}{l}
\text { Control colony growth radius }- \\
\text { Tratment colony growth radius }
\end{array}}{\text { Control colony growth radius }} \times 100
$$

Optimization methods of the fermentation medium. The effects of sucrose, lactose, glucose, starch, citric acid, sodium acetate and $\mathrm{NaHCO}_{3}$ on the biomass and antibacterial activity of JKB05 were compared with the addition of $1 \%$ peptone as a nitrogen source. The experiment was conducted using shaking flask fermentation, and a 300$\mathrm{ml}$ shaking flask (containing $100 \mathrm{ml}$ culture medium) was selected. The experiment was conducted in triplicate. The rate of inhibition was measured at $25^{\circ} \mathrm{C}$ and $140 \mathrm{rpm}$ for 48 h.

The carbon source (glucose), and $0.5 \%$ of a nitrogenous compound was added to the flask. After shaking flask fermentation, the effects of common nitrogen sources (peptone, beef extract, yeast extract, urea, soybean powder, tryptone, and ammonium sulfate) on the antibacterial activity and growth of JKB05 were determined and repeated three times.

First, the carbon and nitrogen sources were fixed, and the effects of $0.05 \%$ of common organic salts $(\mathrm{KCl}, \mathrm{NaCl}$, $\mathrm{FeCl}_{3}, \mathrm{KH}_{2} \mathrm{PO}_{4}$, and $\mathrm{MgSO}_{4}$ ) on antibacterial activity and growth were compared. A group without inorganic salts was utilized as the control group and repeated three times, and the flasks were shaken and fermented as described above.

The carbon source, nitrogen source and two inorganic salts were preliminarily screened using a single factor test as factors. An orthogonal experimental design $\left[\mathrm{L}_{9}\left(3^{4}\right)\right]$ was performed on the preliminary carbon source $(5 \%, 1 \%$, and $2 \%)$, nitrogen source $(0.1 \%, 0.5 \%$, and $1 \%)$ and inorganic salt $(0.01 \%, 0.05 \%$, and $0.1 \%)$.

Optimization methods of the fermentation conditions. Different amount of seed liquid $\left(10^{8} \mathrm{cfu} / \mathrm{ml}\right)$ to make the initial concentration of fermentation $2 \times 10^{6} \mathrm{cfu} / \mathrm{ml}, 4 \times 10^{6}$ $\mathrm{cfu} / \mathrm{ml}, 6 \times 10^{6} \mathrm{cfu} / \mathrm{ml}, 8 \times 10^{6} \mathrm{cfu} / \mathrm{ml}, 1 \times 10^{7} \mathrm{cfu} / \mathrm{ml}$, and 1.2 $\times 10^{7} \mathrm{cfu} / \mathrm{ml}$ were inoculated respectively, with a $\mathrm{pH}$ of 7.0 and cultured for $72 \mathrm{~h}$ at $25^{\circ} \mathrm{C}, 200 \mathrm{rpm}$ and $100 \mathrm{l} / \mathrm{h}$. This process was repeated three times to detect the antibacterial activity.

A volume of $2 \%$ inoculum was inoculated in the optimal medium at a pH of 7.0 and cultured at $25^{\circ} \mathrm{C}, 200 \mathrm{rpm}$, and $100 \mathrm{l} / \mathrm{h}$ ventilation. The fermentation broth was extracted every $6 \mathrm{~h}$ from the beginning stage to $72 \mathrm{~h}$ to detect its antibacterial activity, and the experiment was repeated three times.

Screening methods of nanomaterials. Nano- $\mathrm{TiO}_{2}(99 \%$ metal basis, $\leq 100 \mathrm{~nm})$, nano- $\mathrm{SiO}_{2}(99.5 \%$ metal basis, 30 $\mathrm{nm})$, nano- $\mathrm{CeO}_{2}(99.5 \%$ metal basis, $20 \mathrm{~nm}-50 \mathrm{~nm})$, nano$\mathrm{ZnO}(99.9 \%$ metal basis, $\leq 100 \mathrm{~nm})$, nano-Fe ( $99.9 \%$ metal basis, $30 \mathrm{~nm}$ ), and nanocarbon ( $99.5 \%$ metal basis, $30 \mathrm{~nm}$ ) were screened. All the nanomaterials were from the Shanghai Aladdin Biochemical Technology Co. Ltd. (Shanghai, China).

Effect of NPs on bacteria: nanomaterials at the concentrations of $0.01 \%, 0.05 \%, 0.1 \%, 0.5 \%, 1 \%$, and $5 \%$ [w/ v]) were mixed with liquid NA medium and then sterilized with high-pressure steam. The bacteria were placed into the shaker at $140 \mathrm{rpm}$ and $25^{\circ} \mathrm{C}$ for $48 \mathrm{~h}$. The activity of biocontrol bacteria was detected using the colony count method (Chen et al., 2019), and the experiment was conducted in triplicate.

Effect on plant pathogenic fungi: nanomaterials at the concentrations of $0.01 \%, 0.05 \%, 0.1 \%, 0.5 \%, 1 \%$, and $5 \%$ $(\mathrm{w} / \mathrm{v})$ were mixed with distilled water and autoclaved. The Oxford cup method was used to assess the bacteriostatic 
effects. $N$. guilinensis was inoculated in the center of the plate, and $120 \mu \mathrm{l}$ of nano samples of various concentrations were placed in the Oxford cup. The control group was treated with sterile water and cultured at $25^{\circ} \mathrm{C}$ until the mycelia of the control group was full of culture medium. The experiment was conducted in triplicate.

Method of detection for the influence of nanomaterials on the stability of antagonistic bacteria

Test method of thermal stability. the fermentation broth was taken with a $1.5-\mathrm{ml}$ sterile centrifugal tube in an ultraclean platform, placed in a $30^{\circ} \mathrm{C}, 45^{\circ} \mathrm{C}, 60^{\circ} \mathrm{C}, 75^{\circ} \mathrm{C}, 90^{\circ} \mathrm{C}$, or $100^{\circ} \mathrm{C}$ water bath for $30 \mathrm{~min}$, and then cooled to room temperature.

Test method of acid-base stability. the NA medium was adjusted to $\mathrm{pH} 4.0,5.0,6.0,7.0,8.0,9.0,10.0$, and 11.0 with $0.1 \mathrm{~mol} / 1 \mathrm{NaOH}$ and $0.1 \mathrm{~mol} / \mathrm{l} \mathrm{HCl}$ and then sterilized to make the medium to detect the biocontrol activity.

Test method of UV stability. the fermentation broth was removed using a $1.5-\mathrm{ml}$ sterile centrifugal tube, placed under a $28 \mathrm{~W}$ ultraviolet lamp, and irradiated for 15, 30, 45,60 , and $75 \mathrm{~min}$ at a distance of $10 \mathrm{~cm}$. The biocontrol bacterial activity was detected by the colony count method, and each treatment was repeated three times.

Screening methods for carriers and the additives of biocontrol agents. The widely used carriers and additives are presented in Table 1. First, $0.1 \mathrm{ml}$ of $10^{4}, 10^{5}$, and $10^{6}$ solutions of diluted fermentation broth of the biocontrol bacteria were spread on media that contained different carriers and additives. The mixing ratio is presented in Table 1. NA medium was used as a control, and each treatment was repeated three times. The cells were cultured at $25^{\circ} \mathrm{C}$ for 3 days, and the number of colonies in each medium was recorded. The orthogonal experimental method $\left[\mathrm{L}_{9}\left(3^{4}\right)\right]$ was performed with the carrier, and the adjuvant was screened (Crijns et al., 2006). The activity and suspension rate were measured to determine the proportion of each component.
Preparation and quality test of wettable powder. The procedure of biocontrol bacteria preparation was performed as follows: The protectants that were applied were mixed with the fermented solution and freeze-dried, and the resulting powder sample was mixed with the other assistant agents (Liu et al., 2014). After altering the $\mathrm{pH}$ to 6-7 and smashing until $95 \%$ of it was sieved to $45 \mu \mathrm{m}$, the final preparation was performed and ready for quality testing. The colony count method was used to record the colony number and determine the effect of processing on spore activity.

Based on the plate colony count method, Na medium was selected to detect the bacteria in the samples, and PDA medium was selected to detect the fungi in the samples. The total number of visible bacterial colonies was counted to obtain the number of microbial contaminants (Gibreel et al., 2009). The detection indices $\mathrm{pH}$ (Collaborative International Pesticides Analytical Council, 1970a), fineness (Collaborative International Pesticides Analytical Council, 1970f), wet time (Collaborative International Pesticides Analytical Council, 1970e), suspension rate (Collaborative International Pesticides Analytical Council, 1970b), storage stability (Collaborative International Pesticides Analytical Council, 1970d), and drying loss (Collaborative International Pesticides Analytical Council, 1970c) refer to the standards issued by the Collaborative International Pesticides Analytical Council.

Control effect of $P$. chinense in pot experiments. The pot experiment was performed in the greenhouse at Sichuan Agricultural University. The $N$. guilinensis solution with a spore concentration of $1 \times 10^{6} \mathrm{cfu} / \mathrm{ml}$ was prepared in advance. A total of 13 treatments were established, including wettable powder prepared by the screened biocontrol bacteria and WP prepared by the screened biocontrol bacteria without the addition of nanomaterials diluted with sterile distilled water 50-fold, 100-fold, 200-fold, 500-fold, and 1,000 -fold as the experimental group. A volume of $50 \%$ carbendazim WP (Sichuan Guoguang Agrochemical Co. Ltd., Sichuan, China) was diluted 500-fold as the control, and $0.1 \%$ nano- $\mathrm{SiO}_{2}(99.5 \%$ metal basis, $30 \mathrm{~nm})$ was also

Table 1. List of carriers, additives and mixing proportions used in this study

\begin{tabular}{|c|c|c|}
\hline Name & Materials to be selected & Mixing ratio \\
\hline Carrier & Kaolin, diatomite, calcium carbonate, bentonite, and talc powder & $5 \%(\mathrm{w} / \mathrm{v})$ \\
\hline Wetting agent & Sodium dodecyl benzene sulfonate, Tween 20 , Kaifa powder, saponin powder, and tea seed powder & $250 \mu \mathrm{g} / \mathrm{ml}$ \\
\hline Dispersant & $\begin{array}{l}\text { Sodium lignosulfonate, sodium tripolyphosphate, sodium carboxymethyl cellulose, polyvinyl alco- } \\
\text { hol and polyethylene glycol }\end{array}$ & $1,500 \mu \mathrm{g} / \mathrm{ml}$ \\
\hline Protectants & Sodium dodecanoate, sodium dodecyl sulfate, and ascorbic acid & $50 \mu \mathrm{g} / \mathrm{ml}$ \\
\hline
\end{tabular}


used as a control. The water treatment was a blank control, which was assessed in triplicate. A total of 108 2-year-old $P$. chinense seedlings were selected and divided into three groups as follows: (1) First, the leaves were sprayed with a $100 \mathrm{ml}$ solution of the pathogen. After 15 days, different concentrations of wettable powder were sprayed on the leaves. (2) Different concentrations of wettable powder were inoculated first, and then the pathogen suspension was inoculated 15 days later. (3) The pathogen and different concentrations of wettable powder were inoculated simultaneously. The incidence rate, disease index and control effect were observed 30 days later.

Statistics and data analysis. The experimental data were analyzed using Origin 2018 (OriginLab, Northampton, MA, USA) and SPSS version 22.0 (IBM Corp., Armonk, NY, USA).

\section{Results}

Isolation and purification of the biocontrol bacteria. A total of 48 Bacillus isolates were isolated from the healthy leaves of $P$. chinense and numbered JKB01-JKB48.

Screening of the biocontrol strains against $N$. guilinen-
Table 2. Antagonistic effect of the primary rescreening strains on pathogen $\mathrm{PHC} 1904$

\begin{tabular}{ccc}
\hline Strains number & $\begin{array}{c}\text { Diameter of colony } \\
(\mathrm{cm})\end{array}$ & $\begin{array}{c}\text { Inhibition rate } \\
(\%)\end{array}$ \\
\hline JKB01 & $2.5 \pm 0.12 \mathrm{~cd}$ & $65.27 \pm 0.63 \mathrm{~b}$ \\
JKB05 & $1.2 \pm 0.23 \mathrm{e}$ & $83.33 \pm 0.32 \mathrm{a}$ \\
JKB14 & $4.6 \pm 0.13 \mathrm{~b}$ & $36.11 \pm 1.81 \mathrm{e}$ \\
JKB30 & $3.42 \pm 0.40 \mathrm{c}$ & $52.5 \pm 0.22 \mathrm{c}$ \\
JKB31 & $3.98 \pm 0.32 \mathrm{c}$ & $44.72 \pm 1.81 \mathrm{~d}$ \\
JKB46 & $2.33 \pm 0.45 \mathrm{~cd}$ & $67.63 \pm 0.26 \mathrm{~b}$ \\
CK & $7.2 \pm 0.3 \mathrm{a}$ & - \\
\hline
\end{tabular}

Values are presented as the mean $\pm \mathrm{SD}$, and data with different lowercase letters indicate significant differences at the 0.05 level.

sis. The 48 strains of isolated Bacillus were tested against $N$. guilinensis, and six strains of Bacillus with antagonistic effects were identified. The mycelial growth of $N$. guilinensis was significantly inhibited compared with the control. The mycelia near Bacillus grew sparsely, and an obvious inhibition zone appeared. The strains JKB01, JKB05, JKB14, JKB30, JKB31, and JKB46 were highly antagonistic to the pathogenic fungi (Table 2).

Strain JKB05 was found to be strongly bacteriostatic. The diameter of the $N$. guilinensis colony was $1.2 \pm 0.23$ $\mathrm{cm}$, and the rate of inhibition was $83.33 \%$ (Table 2). Com-

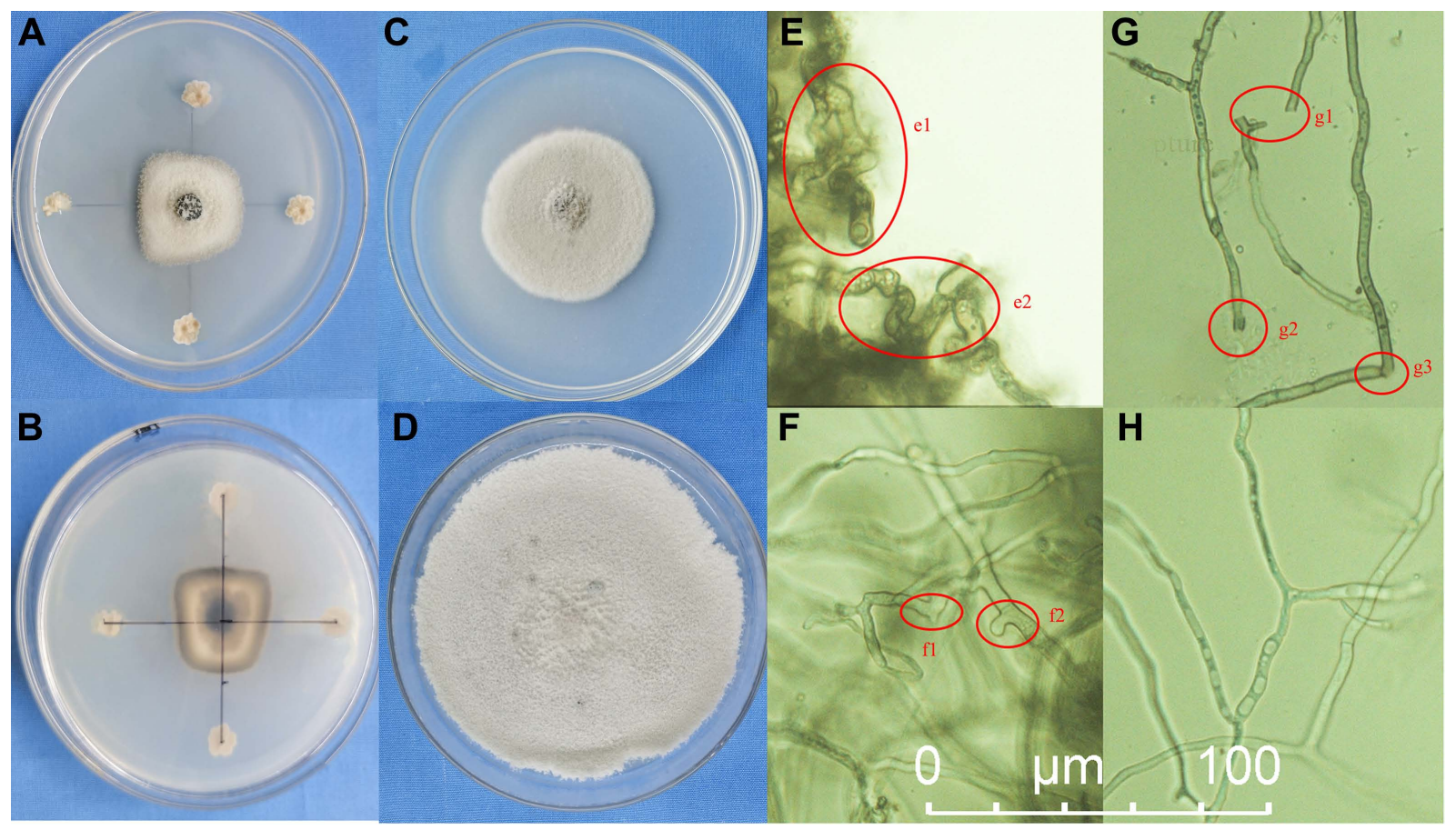

Fig. 1. (A, B) Plate confrontation growth test of JKB05 to PHC1904, 7 days. (C) Rescreening experiment, 7 days. (D) Control check, PHC1904 on potato dextrose agar culture medium, 7 days. (E-H) Micrograph of marginal hyphae of PHC1904 sharing the same scale bar. (H) Normal hyphal. e1, e2, swollen hyphae and disordered growth; g1, g2, g3, broken hyphae; f1, f2, abnormal hyphae. 


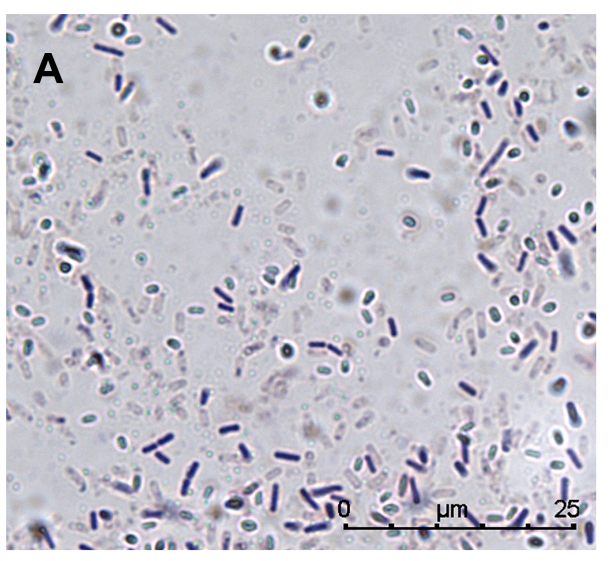

C

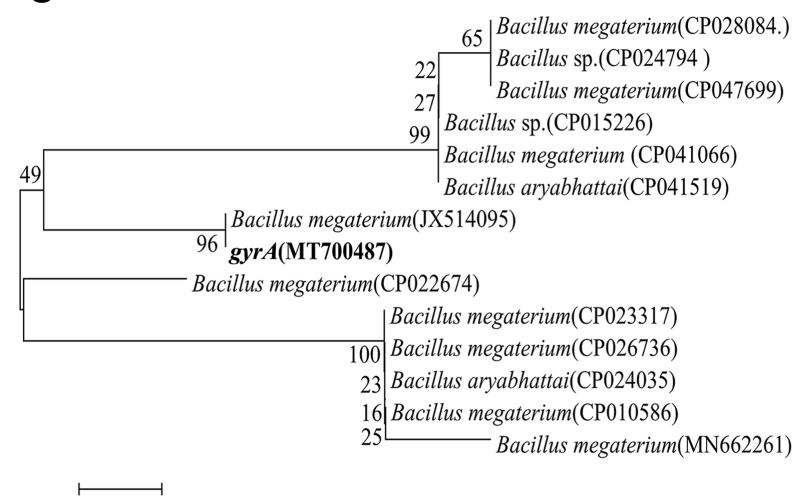

0.002

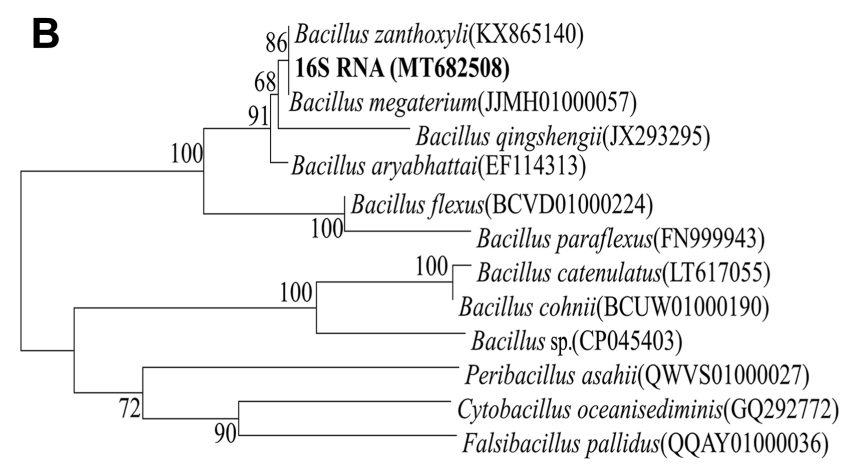

0.005

D

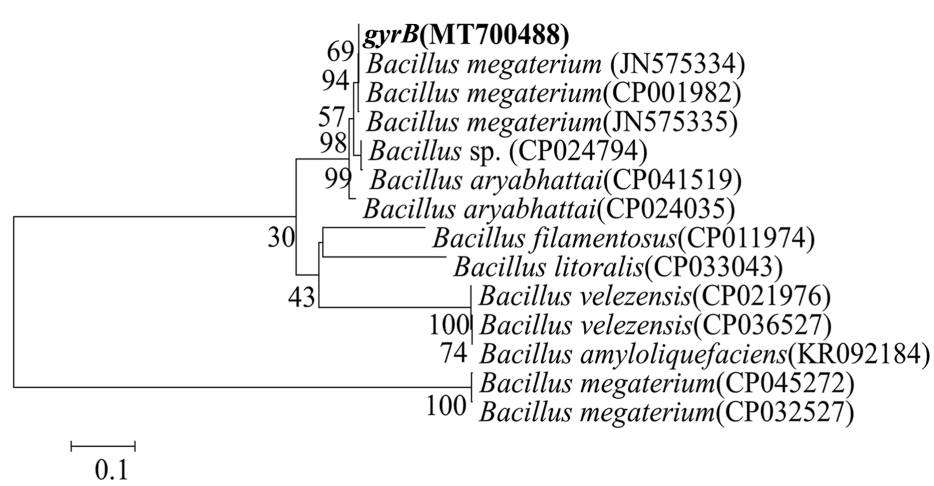

Fig. 2. (A) Micromorphology of strain JKB05 (mycelium and spores, $\times 100$ ). (B) Phylogenetic tree of strain JKB05 16S rRNA gene sequence (MT682508). (C) Phylogenetic tree of strain JKB05 gyrA gene sequence (MT700487). (D) Phylogenetic tree of strain JKB05 gyrB gene sequence (MT700488). The number in brackets is the accession number of the strain in ezbiocloud or GenBank. The phylogram was constructed by the neighbor-joining method. The percentage of replicate trees in which the associated taxa clustered together in the bootstrap test (1,000 replicates) are shown next to the branches. The evolutionary distances were computed using the p-distance method. The scale bar indicates the average number of amino acid substitutions per site.

pared with the control, the hyphae on the edge of the $N$. guilinensis colony were few and sparse, and the mycelial growth regressed and was obviously inhibited. The edge of the inhibited colonies exhibited a black pigment, and healthy and inhibited hyphae were observed under the microscope. As shown in Fig. 1C, D, G, and H, the mycelial growth was severely inhibited, and some hyphae were destroyed. Combined with the results of the preliminary screening test, strain JKB05 exhibited a strong antagonistic effect on $N$. guilinensis, which was stable and increased significantly compared with the other five strains. Therefore, strain JKB05 was selected as the target Bacillus for subsequent experiments.

Identification of strain JKB05. On NA solid medium (Supplementary Fig. 1A), the growth heaped and was nonspreading, moderately dull, occasionally slightly rugose; and usually some shade of yellow after aging. Following a long incubation, the growth and media become brown. Microscopic observation showed that the strain was rodshaped. The rod was 1.2-1.5 $\mu \mathrm{m}$ wide and 2-5 $\mu \mathrm{m}$ long. The rods were straight or slightly curved. The spores varied from round to elongate or ellipsoidal, and the central spores exhibited round strain instability. There was no obvious swelling of the sporangia (Fig. 2A). The physiological and biochemical characteristics of strain JKB05 are shown in Table 3.

After PCR amplification, 948 bp (16S RNA), 803 bp $(g y r A)$, and 980 bp $($ gry $B)$ bands were observed using $1 \%$ agarose gel electrophoresis (Supplementary Fig. 1B-D).

The phylogenetic tree (Fig. 2B-D) based on the 16S rRNA, gyrA, and gyrB genes showed that strain JKB05 was the most closely related to Bacillus megaterium and located in the same branch. Therefore, strain JKB05 was 
Table 3. Physiological and biochemical characteristics of strain JKB05

\begin{tabular}{lc}
\hline Characteristic & JKB05 \\
\hline Physiological & + \\
Gram staining & + \\
Catalase & \\
Hydrolysis & + \\
Casein & + \\
Gelatin & + \\
Starch & \\
Biochemical & - \\
Anaerobic growth & \\
Utilization & + \\
Citrate & - \\
Egg-yolk lecithinase & - \\
Parasporal crystals & - \\
Sporangium swollen & \\
\hline
\end{tabular}

- , negative; + , positive.
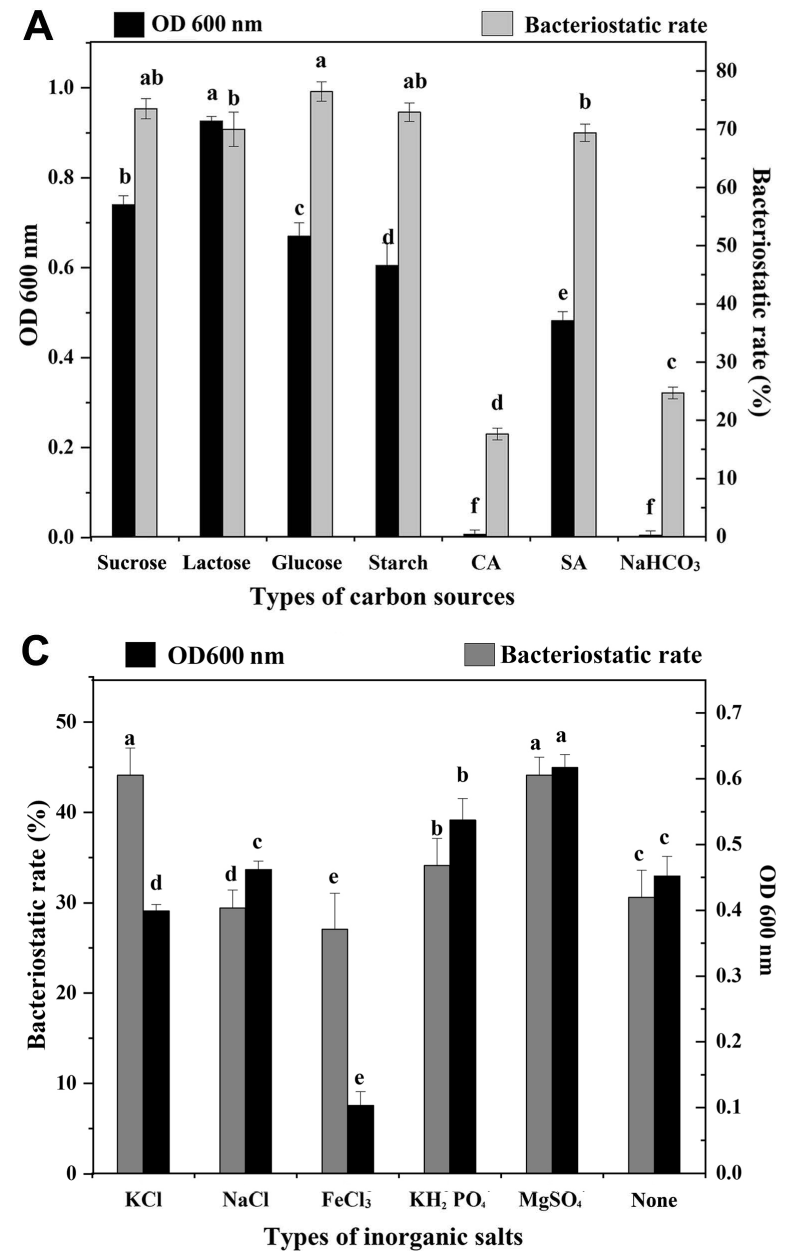

Fig. 3. (A) Screening results of carbon sources. (B) Screening results of nitrogen sources. (C) Screening results of inorganic salts. Data with different lowercase letters indicate significant differences at the 0.05 level; the error bar indicates the uncertainty of the measured data. CA, citric acid; SA, sodium acetate; YEF, yeast extract; SP, soybean powder; AS, ammonium sulfate. identified as B. megaterium based on its morphological characteristics, physiological and biochemical characteristics (Krieg et al., 2011) and the sequence alignment of $16 \mathrm{~S}$ rRNA, gyrA and gyrB genes. In addition, B. megaterium could be easily recognized in microscopic preparations by its typical cell morphology.

Optimization results of fermentation medium and conditions. As shown in Fig. 3, glucose with the highest bacteriostatic rate $(76.47 \%)$ was selected as the best carbon source, and AS was the best nitrogen sources. At the same time, tryptone and soybean powder had similar antibacterial rates $(73.53 \%$ and $72.94 \%$, respectively), but tryptone was more expensive and not suitable for wettable powders. From an economic point of view, soybean powder was selected as the best nitrogen source. In addition, $\mathrm{KCl}$ and $\mathrm{MgSO}_{4}$ were selected as the best inorganic salts because they had the highest and similar bacteriostatic rates. The

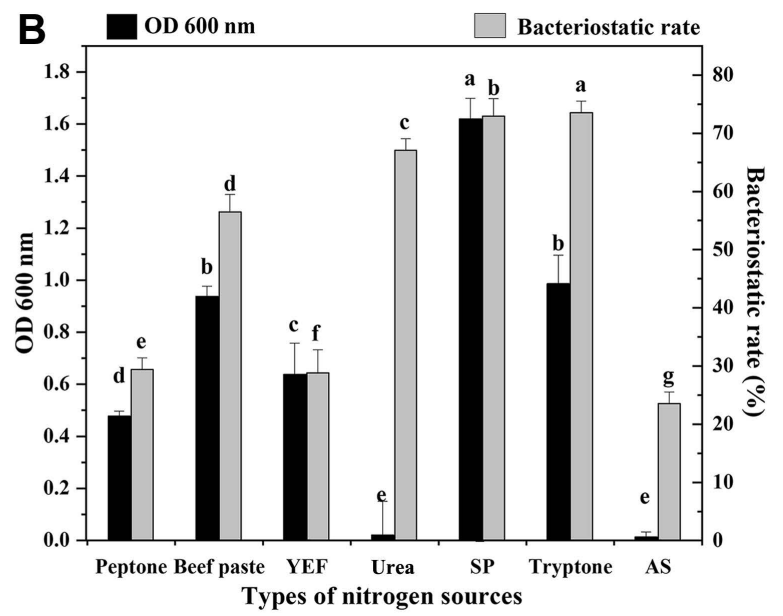

Types of nitrogen sources 
Table 4. The orthogonal test statistics results of optimum fermentation medium

\begin{tabular}{|c|c|c|c|c|c|}
\hline \multirow{2}{*}{ No. } & \multicolumn{4}{|c|}{ Experimental factors } & \multirow{2}{*}{ BR (\%) } \\
\hline & Glucose & Soybean powder & $\mathrm{KCl}$ & $\mathrm{MgSO}_{4}$ & \\
\hline 1 & $0.50 \%$ & $0.10 \%$ & $0.01 \%$ & $0.01 \%$ & $61.54 \pm 0.27 \mathrm{~d}$ \\
\hline 2 & $0.50 \%$ & $0.50 \%$ & $0.05 \%$ & $0.05 \%$ & $62.31 \pm 0.36 \mathrm{~d}$ \\
\hline 3 & $0.50 \%$ & $1.00 \%$ & $0.10 \%$ & $0.10 \%$ & $53.08 \pm 0.13 \mathrm{e}$ \\
\hline 4 & $1.00 \%$ & $0.10 \%$ & $0.05 \%$ & $0.10 \%$ & $56.92 \pm 0.32 \mathrm{e}$ \\
\hline 5 & $1.00 \%$ & $0.50 \%$ & $0.10 \%$ & $0.01 \%$ & $73.85 \pm 0.12 b$ \\
\hline 6 & $1.00 \%$ & $1.00 \%$ & $0.01 \%$ & $0.05 \%$ & $69.20 \pm 0.26 \mathrm{~cd}$ \\
\hline 7 & $2.00 \%$ & $0.10 \%$ & $0.10 \%$ & $0.05 \%$ & $78.46 \pm 0.14 \mathrm{a}$ \\
\hline 8 & $2.00 \%$ & $0.50 \%$ & $0.01 \%$ & $0.10 \%$ & $73.08 \pm 0.16 b$ \\
\hline 9 & $2.00 \%$ & $1.00 \%$ & $0.05 \%$ & $0.01 \%$ & $70.69 \pm 0.15 \mathrm{c}$ \\
\hline K1 & 176.93 & 196.92 & 203.82 & 206.08 & \\
\hline $\mathrm{K} 2$ & 199.97 & 209.24 & 189.92 & 209.97 & \\
\hline K3 & 222.23 & 192.97 & 205.39 & 183.08 & \\
\hline $\mathrm{R}$ & 45.3 & 16.27 & 15.47 & 26.89 & \\
\hline
\end{tabular}

Values are presented as the mean $\pm \mathrm{SD}$, and data with different lowercase letters indicate significant differences at the 0.05 level.

$\mathrm{BR}$, bacteriostatic rate; $\mathrm{Ki}$ (column $\mathrm{m})=$ the sum of the number in column $\mathrm{m}$ corresponding to the ' $\mathrm{i}$ ' index; $\mathrm{R}$, range, $\mathrm{R}($ column $\mathrm{m})=$ the difference between the maximum and the minimum in each average of column $\mathrm{m} \mathrm{K} 1$, $\mathrm{K} 2$, etc.

analysis of data indicated that the order of the four factors on the bacteriostatic rate of JKB05 was glucose $>$ magnesium sulfate $>$ soybean powder $>$ potassium chloride (Table 4). The formula for optimal fermentation medium was $2 \%$ glucose, $0.1 \%$ soybean powder, $0.1 \% \mathrm{KCl}$, and $0.05 \%$ $\mathrm{MgSO}_{4}$.

The effect of initial concentration on the growth of the strain and the production of antibacterial active substances is presented in Fig. 4A. When the initial concentration was $2 \times 10^{6} \mathrm{cfu} / \mathrm{ml}-1.2 \times 10^{7} \mathrm{cfu} / \mathrm{ml}$, the strain grew well, and the fermentation broth exhibited antibacterial activity. When the initial concentration was $6 \times 10^{6} \mathrm{cfu} / \mathrm{ml}$, the biomass reached the maximum value, and the antibacterial activity was also strong. With the increase of initial concentration, the antibacterial activity did not increase. This finding could be because the volume of the inoculum was too large, resulting in the rapid growth of the strain and insufficient dissolved oxygen and thereby affecting the formation of antibacterial substances. Therefore, the optimal initial concentration is $6 \times 10^{6} \mathrm{cfu} / \mathrm{ml}$. On the other hand, When
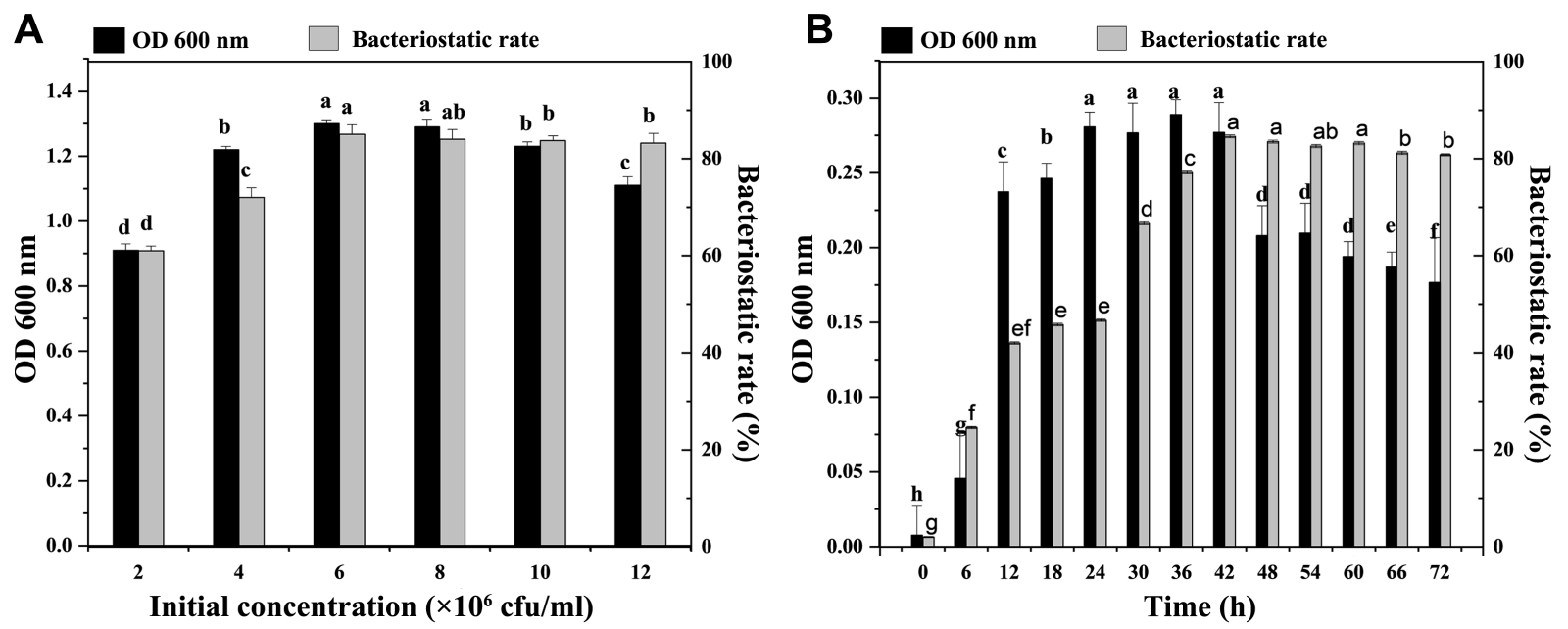

Fig. 4. (A) Effect of initial concentration on the bacteriostatic rate and growth quantity. (B) Effect of fermentation duration on bacteriostatic rate and growth quantity. Data with different lowercase letters indicate significant differences at the 0.05 level; the error bar indicates the uncertainty of the measured data. 


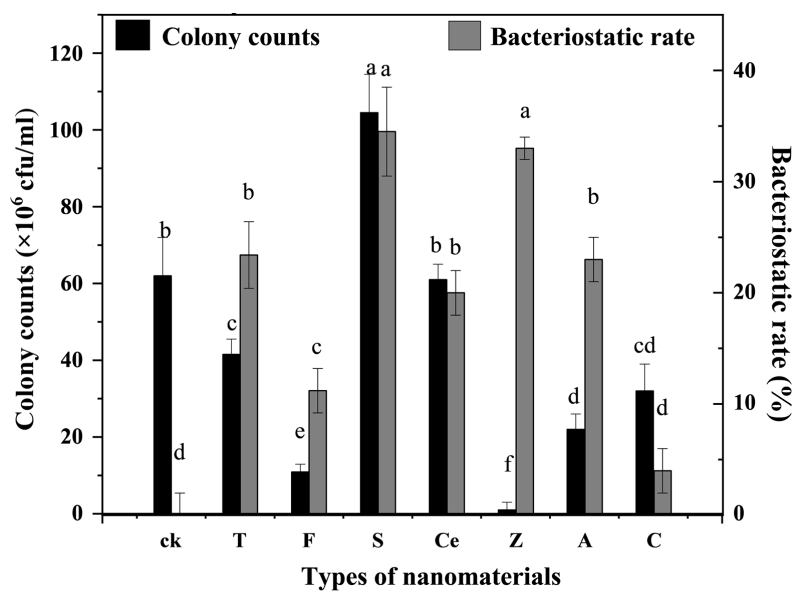

Fig. 5. The effect of different nanometer materials on the activity of JKB05. CK, control; T, nano- $\mathrm{TiO}_{2}$; F, nano-Fe; S, nano- $\mathrm{SiO}_{2}$; $\mathrm{Ce}$, nano- $\mathrm{CeO}_{2} ; \mathrm{Z}$, nano- $\mathrm{ZnO} ; \mathrm{A}$, nano- $\mathrm{Al}_{2} \mathrm{O}_{3} ; \mathrm{C}$, nano carbon. the fermentation time was $0-42 \mathrm{~h}$, the number of viable bacteria and the antibacterial rate gradually increased and reached a stable value at $42 \mathrm{~h}$. At $42-72 \mathrm{~h}$, as the culture time increased, the number of viable bacteria decreased significantly, and the antibacterial rate remained stable. According to these results, $42 \mathrm{~h}$ was the optimal fermentation time (Fig. 4B).

Based on the results described above, 2\% glucose, $0.1 \%$ soybean powder, $0.1 \% \mathrm{KCl}$, and $0.05 \% \mathrm{MgSO}_{4}$ were selected as the optimal medium with $6 \times 10^{6} \mathrm{cfu} / \mathrm{ml}$ initial concentration, and the fermentation time was set as $42 \mathrm{~h}$.

Screening and stability test results of the nanomaterials. In Fig. 5, the addition of $\mathrm{SiO}_{2}(99.5 \%$ metal basis, $30 \mathrm{~nm})$ improved the biocontrol activity of $B$. megaterium JKB05 and was highly biocompatible. nano-ZnO (99.9\% metal
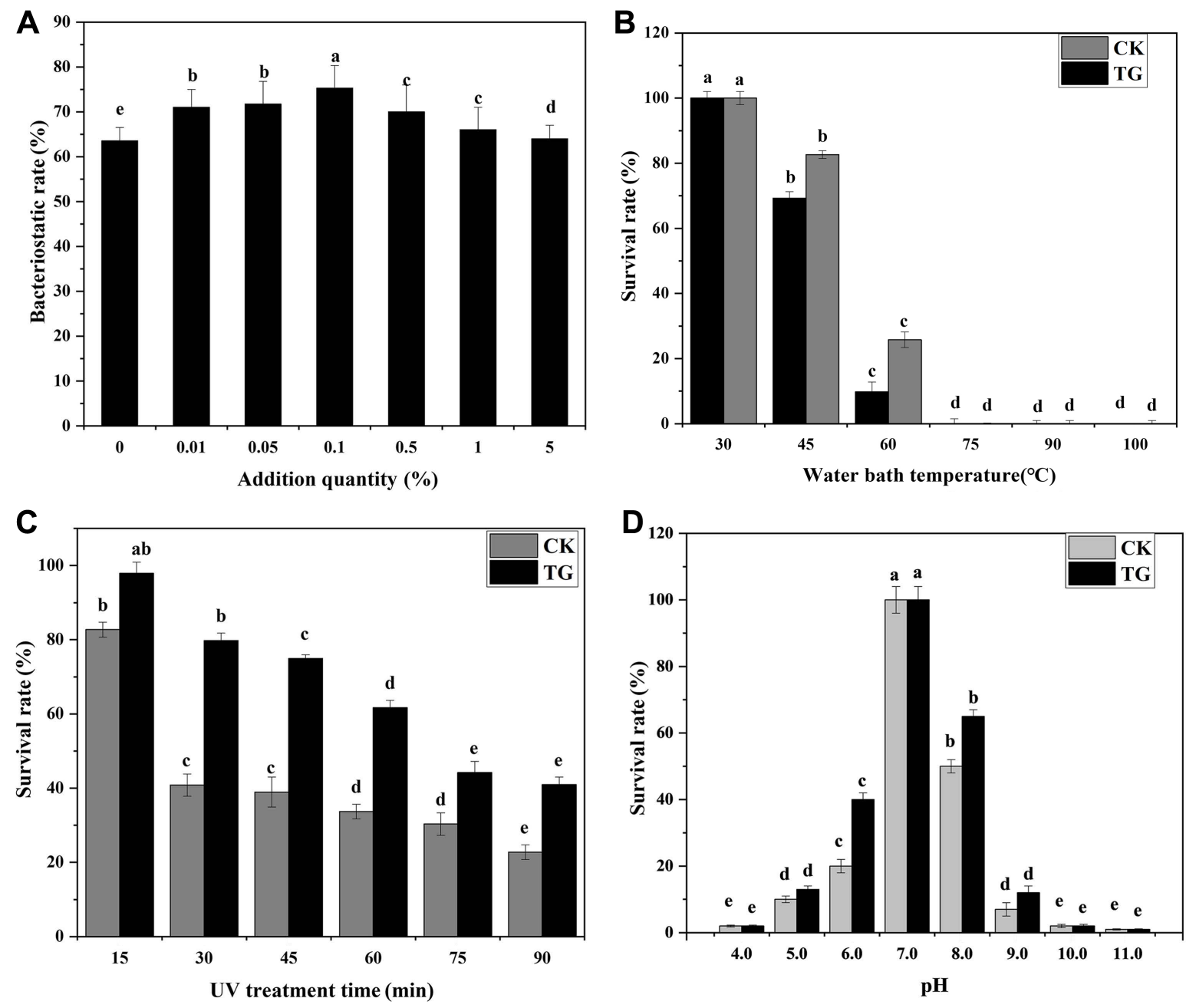

Fig. 6. (A) Effect of different dosages of $\mathrm{SiO}_{2}(99.5 \%$ metal basis, $30 \mathrm{~nm})$ on the inhibition rate of JKB05. (B) Thermal stability test results of JKB05. (C) UV stability test results of JKB05. (D) Acid-base stability test results of JKB05. Data with different lowercase letters indicate significant differences at the 0.05 level; the error bar indicates the uncertainty of the measured data. TG, the best medium $+0.1 \%$ $\mathrm{SiO}_{2}(99.5 \%$ metal basis, $30 \mathrm{~nm})$; $\mathrm{CK}$, the best medium $+0.1 \%$ sterile water. 
basis, $\leq 100 \mathrm{~nm})$ and nano- $\mathrm{SiO}_{2}(99.5 \%$ metal basis, 30 $\mathrm{nm}$ ) inhibited the growth of $N$. guilinensis. However, the antibacterial rate of nano- $\mathrm{ZnO}$ was broad-spectrum, which inhibited the ability of $B$. megaterium to grow normally. Therefore, $\mathrm{SiO}_{2}(99.5 \%$ metal basis, $30 \mathrm{~nm})$ was selected as the target nanomaterial. In addition, the addition of a small amount of $\mathrm{SiO}_{2}(99.5 \%$ metal basis, $30 \mathrm{~nm})$ to the fermentation medium improved the antibacterial rate of $B$. megaterium JKB05 (Fig. 6A). To avoid reducing the antibacterial rate of biocontrol bacteria, the optimal addition amount was selected as $0.1 \%$.

The thermal stability test results of JKB05 is shown in Fig. $6 \mathrm{~B}$, when the temperature of water bath was $45-60^{\circ} \mathrm{C}$, the survival rate of JKB05 in TG (treatment group) was significantly higher, indicating that the addition of $\mathrm{SiO}_{2}$ (99.5\% metal basis, $30 \mathrm{~nm}$ ) improved the survival rate of
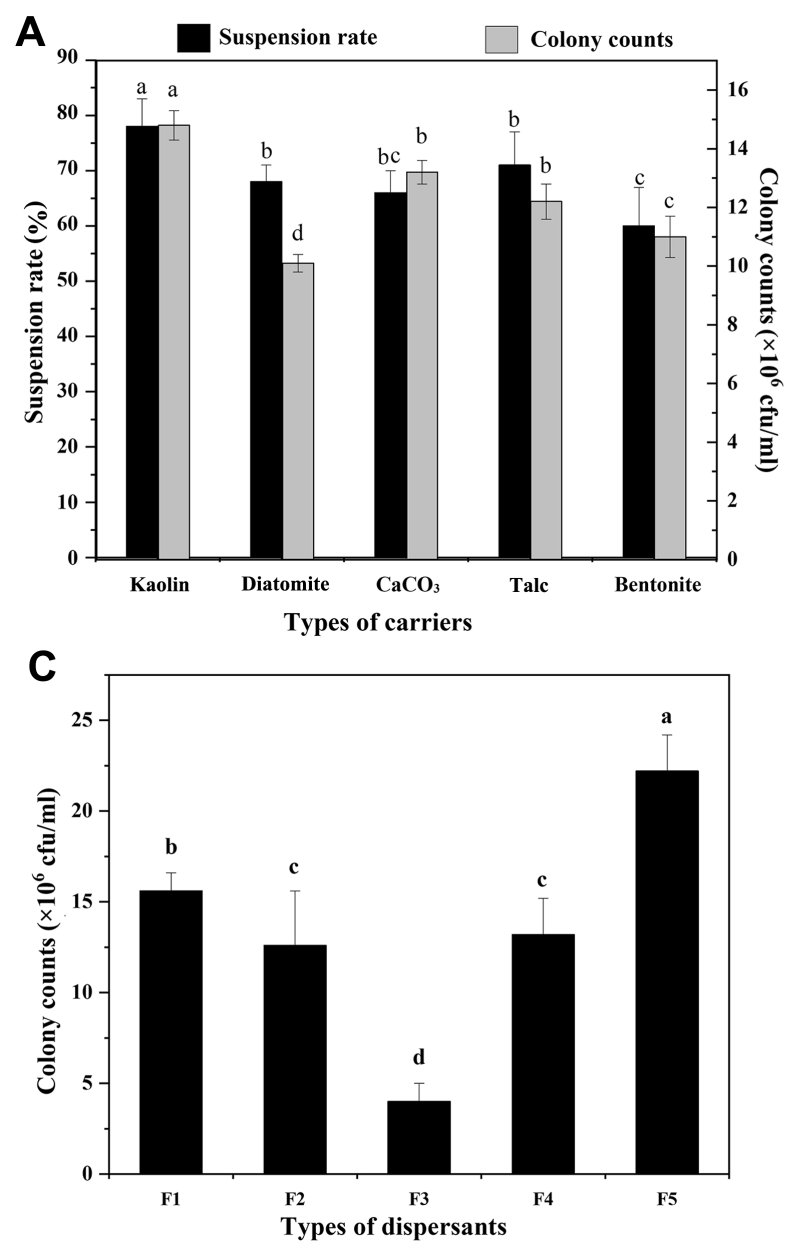

JKB05 by $16 \%$ in a high-temperature environment. When the temperature was $75-100^{\circ} \mathrm{C}$, the $\mathrm{CK}$ (control group) and TG were unable to grow and remained undectable, indicating that the bacteria had been inactivated at higher temperatures. The UV stability test results of JKB05 is shown in Fig. 6C. With the increase in time of UV irradiation, fewer biocontrol bacteria survived, but the survival rate of the TG was always increased compared with that of the CK. The highest rate of survival of JKB05 in the ultraviolet light environment was $38.9 \%$. The acid-base stability test results of JKB05 is presented in Fig. 6D. Colonies could grow in the medium with $\mathrm{pH}$ values of 5.0-9.0 $(\mathrm{pH} \neq 7)$. However, the survival rate of JKB05 in TG was significantly higher, indicating that the addition of $\mathrm{Nano}-\mathrm{SiO}_{2}$ exhibited a protective effect on the biocontrol bacteria, which improved the rate of survival of JKB05 by $12 \%$ in the environment. In
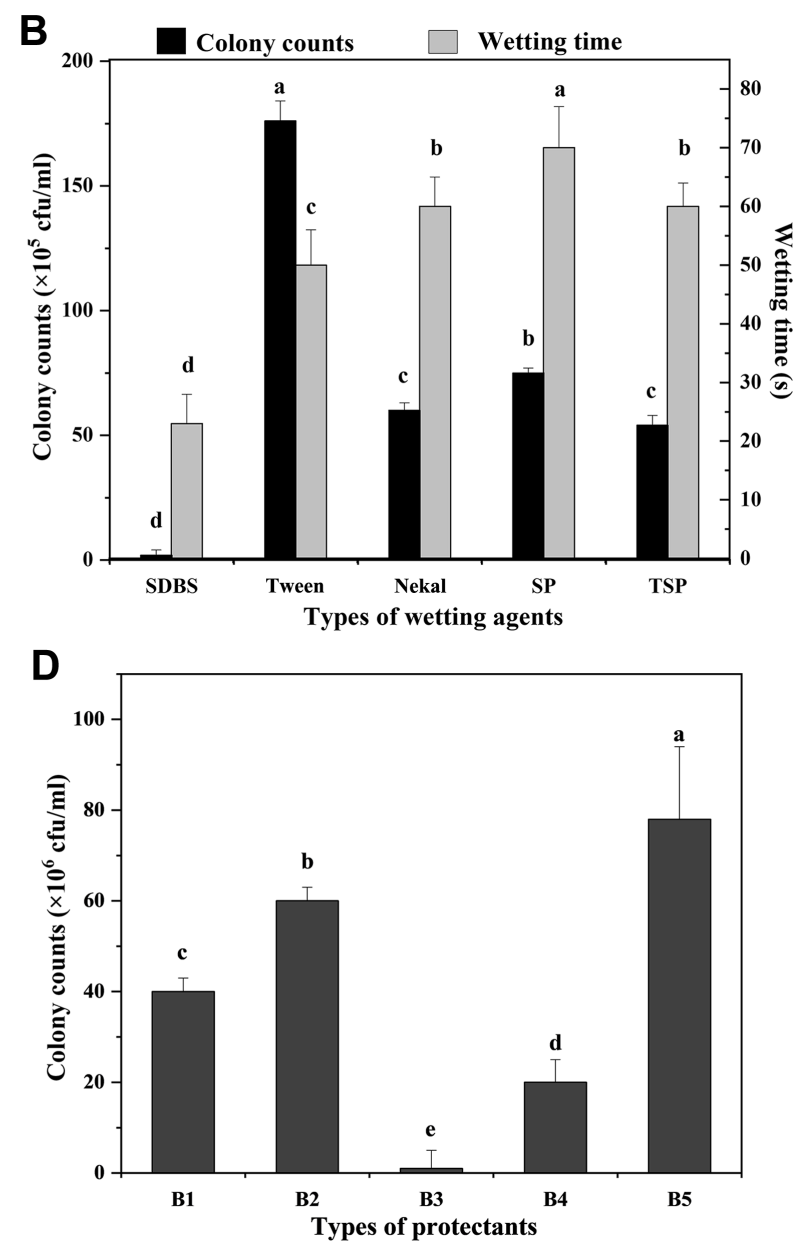

Fig. 7. (A) The effect of different carriers on biocontrol activity. (B) The effect of different wetting agent on biocontrol activity. (C) The effect of different dispersant on biocontrol activity. (D) The effect of different protectants on biocontrol activity. Data with different lowercase letters indicate significant differences at the 0.05 level; the error bar indicates the uncertainty of the measured data. SDBS, sodium dodecyl benzene sulfonate; SP, saponin powder; TSP, tea seed powder; F1, sodium lignosulfonate; F2, sodium tripolyphosphate; F3, sodium carboxymethyl cellulose; F4, polyvinyl alcohol; F5, polyethylene glycol; B1, dextrin; B2, kaolin; B3, sodium dodecyl sulfate; B4, ascorbic acid; B5, humic acid. 
extremely acidic or alkaline environment ( $\mathrm{pH}$ values of 4.0, 10.0, and 11.0), JKB05 showed a very low survival rate for both $\mathrm{CK}$ and $\mathrm{TG}$.

Preparation and quality test results of wettable powder. In Fig. 7A, each carrier has a significant impact on the activity of biocontrol bacteria. Among them, kaolin had the fewest deleterious effects on the activity of biocontrol bacteria and suspended well. In addition, wetting agents had a significant effect on the activity of biocontrol bacteria (Fig. 7B). Of these agents, Tween 20 had the least effect, so it was selected as the wetting agent. Moreover, dispersants had a significant effect on the activity of biocontrol bacteria (Fig. 7C). Among the dispersants, polyethylene glycol (PEG) had the least effect on the activity of biocontrol bacteria, and sodium carboxymethyl cellulose inhibited their activity. Thus, PEG was selected as the dispersant. In Fig. $7 \mathrm{D}$, the five protectants all had significant effects on the activity of biocontrol bacteria. Sodium dodecyl sulfate exhibits an obvious inhibitory effect. Humic acid had the least effect on the activity of biocontrol bacterial. Therefore, it was selected as the protectant. An analysis of variance (ANOVA) showed that each component had a significant impact on the suspension rate and activity of the bacterial agent (Table 5). The suspension rate and wetting time are the main factors that affect the wettable powder. Finally, the optimal ratio was selected as follows: $35 \%$ kaolin, $4 \%$ PEG, $8 \%$ Tween 20, and 2\% humic acid.

The quality test results are shown in Table 6 . The wetting time was $87.0 \mathrm{~s}(<120 \mathrm{~s})$. The suspension rate was $80.33 \%$ $(>70 \%)$. The frequency of microbial contamination was $0.08 \%$. The $\mathrm{pH}$ was 7.2 , and the fineness was $95.8 \%$. The drying loss was $1.47 \%$, and the stability in storage was $\geq 83.5 \%$.

Control effect of the nanowettable powder on potted plants. The results of a pot experiment showed that the addition of nano- $\mathrm{SiO}_{2}(99.5 \%$ metal basis, $30 \mathrm{~nm})$ improved the ability of a wettable powder of JKB05 to control brown leaf spot disease on $P$. chinense. The ability of JKB05 to inhibit the pathogen decreased as its dilution increased (Table 7). Therefore, the powders exhibited different degrees of biocontrol. The control effects of the 50-, 100-, 500 -, and 1,000-fold dilutions were greater than $50 \%$. The 50 -fold dilution was the most effective at controlling $P$. chinense, and the highest amount of control observed was $96 \%$. The comparison of leaf symptoms in the pot experiment is shown in Supplementary Fig. 2. The control effect of nano-JKB05 WP diluted 500-fold was better than that of $50 \%$ carbendazim, but a 1,000-fold dilution was not effec-

Table 5. The carrier and additive ratio optimization of the orthogonal test

\begin{tabular}{|c|c|c|c|c|c|c|}
\hline \multirow{2}{*}{ No. } & \multicolumn{4}{|c|}{ Experimental factors $(\%)$} & \multirow{2}{*}{ WT (s) } & \multirow{2}{*}{ SR (\%) } \\
\hline & Carrier & Dispersant & Wetting agent & Protectants & & \\
\hline 1 & 35 & 3 & 6 & 1.5 & $454 \pm 5.8 \mathrm{c}$ & $78.11 \pm 0.53 \mathrm{ab}$ \\
\hline 2 & 35 & 4 & 8 & 2 & $87 \pm 4.1 \mathrm{f}$ & $80.33 \pm 5.02 \mathrm{a}$ \\
\hline 3 & 35 & 5 & 10 & 2.5 & $36 \pm 1.7 \mathrm{~g}$ & $71.67 \pm 2.62 \mathrm{~cd}$ \\
\hline 4 & 40 & 3 & 8 & 2.5 & $810 \pm 3.3 b$ & $61.89 \pm 1.48 \mathrm{e}$ \\
\hline 5 & 40 & 4 & 10 & 1.5 & $50 \pm 2.5 \mathrm{f}$ & $73.89 \pm 2.48 \mathrm{c}$ \\
\hline 6 & 40 & 5 & 6 & 2 & $104 \pm 2.9 \mathrm{e}$ & $62.56 \pm 3.87 \mathrm{e}$ \\
\hline 7 & 45 & 3 & 10 & 2 & $162 \pm 5.7 \mathrm{e}$ & $69.22 \pm 1.52 \mathrm{~d}$ \\
\hline 8 & 45 & 4 & 6 & 2.5 & $1,524 \pm 2.5 \mathrm{a}$ & $61.22 \pm 2.43 \mathrm{e}$ \\
\hline 9 & 45 & 5 & 8 & 1.5 & $238 \pm 6.8 \mathrm{~d}$ & $75.44 \pm 1.02 \mathrm{~b}$ \\
\hline $\mathrm{K}_{1}$ & 577 & 1,426 & 2,082 & 742 & & \\
\hline $\mathrm{K}_{2}$ & 964 & 1,661 & 1,135 & 353 & & \\
\hline $\mathrm{K}_{3}$ & 1,924 & 378 & 248 & 2,370 & & \\
\hline $\mathrm{R}$ & 1,347 & 1,283 & 1,834 & 2,017 & & \\
\hline k1 & 231.11 & 210.22 & 202.89 & 228.44 & & \\
\hline k2 & 198.34 & 215.44 & 217.66 & 212.11 & & \\
\hline $\mathrm{k} 3$ & 205.88 & 209.67 & 214.78 & 194.78 & & \\
\hline $\mathrm{r}$ & 32.77 & 5.77 & 14.77 & 33.66 & & \\
\hline
\end{tabular}

Values are presented as the mean $\pm \mathrm{SD}$, and data with different lowercase letters indicate significant differences at the 0.05 level. WT, wetting time; SR, suspension rate; $\mathrm{Ki}$ (column $\mathrm{m}$ ) = the sum of the number in column $\mathrm{m}$ corresponding to the ' $\mathrm{i}$ 'index; $\mathrm{R}$, range; $\mathrm{R}$ (column $\mathrm{m})=$ the difference between the maximum and the minimum in each average of column $\mathrm{m} \mathrm{K} 1$, $\mathrm{K} 2$, etc. 
Table 6. Results of quality inspection of wettable powder of JKB05

\begin{tabular}{lcc}
\hline Index & National standards & Actual value \\
\hline Frequency of microbial contamination (\%) & $\leq 3$ & 0.08 \\
$\mathrm{pH}$ & $5.0-8.0$ & 7.2 \\
Fineness (\%) & $\geq 90$ & 95.8 \\
Wetting time (s) & $\leq 180$ & 87.0 \\
Suspension rate (\%) & $\geq 70$ & 80.33 \\
Drying loss (\%) & $\leq 6$ & 1.47 \\
Storage stability (\%) & $\geq 80$ & 83.5 \\
\hline
\end{tabular}

Table 7. Control effects of Bacillus megaterium JKB05 wettable powder on pepper dry rot in potted tests

\begin{tabular}{|c|c|c|c|c|c|c|c|c|c|}
\hline \multirow{2}{*}{ Treatment } & \multicolumn{3}{|c|}{ Pathogenic fungus first } & \multicolumn{3}{|c|}{ Biocontrol bacteria first } & \multicolumn{3}{|c|}{ Simultaneous inoculation } \\
\hline & IR & DI & $\mathrm{CE}$ & IR & DI & $\mathrm{CE}$ & IR & DI & $\mathrm{CE}$ \\
\hline & $2+1$ & 7007 & 20 & 10 & & & +00 & & \\
\hline KB05 & $22.6 \pm 1.55 \mathrm{e}$ & $16.1=$ & & & & & $10.2 \pm 0.74 \mathrm{e}$ & & \\
\hline & $\pm 1.93 \mathrm{~d}$ & $20 \pm 0$ & b & & & & $16 \pm 0.1 \mathrm{e}$ & & \\
\hline KB05× & $1.55 \mathrm{e}$ & & & & & & $13.8 \pm 0.97 \mathrm{e}$ & & \\
\hline$A \times 200$ & $32.5 \pm 1.73 \mathrm{c}$ & $23.2 \pm 0$ & & & & & $23 \pm 0.21 \mathrm{~d}$ & $16.4 \pm 0.63 \mathrm{c}$ & \\
\hline JKBO & $28.6=$ & & & & & & $18.5 \pm 0.04 \mathrm{~d}$ & $1 \mathrm{c}$ & \\
\hline$A \times 500$ & $3.7 \pm 2.6 \mathrm{~b}$ & & & & & & $30 \pm 0.3$ & $55 \mathrm{~b}$ & \\
\hline JKB0 & $32.6 \pm 1.8 \mathrm{c}$ & $23.3 \pm 0.4$ & $67 \pm 0.49 b c$ & $=0.16 \mathrm{c}$ & & & $22.7 \pm 0.17 \mathrm{~d}$ & $16.2 \pm 0.47 \mathrm{c}$ & \\
\hline$A \times 1000$ & $47.3 \pm 1.12$ & $33.8 \pm 0.1 \mathrm{~b}$ & $52 \pm 2.6 \mathrm{~d}$ & $32.8 \pm 1.4 \mathrm{~b}$ & $23.4 \pm 0$ & $67 \pm 0.65 \mathrm{~d}$ & $40.1 \pm 0.67 b$ & $28.6 \pm 0.89 b$ & \\
\hline JKB05 & $42.5 \pm 3.97$ & $30.4 \pm 1.2 b$ & & $26.8 \pm 0.77 b c$ & $19.1 \pm 0$. & $73 \pm 0.28 d$ & $35.7 \pm 1.62 b$ & $25.5 \pm 1.74 b$ & \\
\hline Nano- $\mathrm{SiO}_{2}$ & $45.3 \pm 1.81 b$ & $32.4 \pm 0.19 b$ & $55 \pm 3.1 \mathrm{c}$ & $36.7 \pm 1.8 b$ & $26.2 \pm 0.71 b$ & $64 \pm 1.53 \mathrm{e}$ & $38.4 \pm 0.24 b$ & $27.4 \pm 0.83 b$ & $62 \pm 0.36 \mathrm{e}$ \\
\hline $\mathrm{G} \times 500$ & $33.5 \pm 0.42 c$ & $23.9 \pm 0.17 \mathrm{c}$ & $66 \pm 1.53 b c$ & $12 \pm 0.61 \mathrm{~d}$ & $8.6 \pm 0.96 \mathrm{~d}$ & $88 \pm 0.17 b c$ & $15 \pm 0.7 \mathrm{e}$ & $10.7 \pm 0.98 \mathrm{c}$ & $85 \pm 1.31 \mathrm{~b}$ \\
\hline CK & $93 \pm 0.7 \mathrm{a}$ & $66.4 \pm 0.22 \mathrm{a}$ & - & $89 \pm 0.44 \mathrm{a}$ & $56 \pm 0.83 \mathrm{a}$ & - & $87 \pm 0.86 \mathrm{a}$ & $62 \pm 1.69 \mathrm{a}$ & - \\
\hline
\end{tabular}

Data with different lowercase letters indicate significant differences at the 0.05 level.

IR, incidence rate; DI, disease index; CE, control effect; A, JKB05 wettable powder without nanomaterial added; JKB05, JKB05 wettable powder with nanomaterial added; G, 50\% carbendazim; CK, sterile water; $\times \mathrm{n}$, $\mathrm{n}$ dilutions.

tive. Consequently, the recommended concentration was 500 -fold to provide cost-effective control. If only nano$\mathrm{SiO}_{2}$ is used, the brown leaf spot disease is only partially controlled. The preventive effect of JKB05 increased considerably compared with that of the treatment. This finding may be attributed to the fact that JKB05 colonizes the leaf surface earlier, occupies the habitat and reduces the rate of infection of $N$. guilinensis. When the plant has been infected by $N$. guilinensis, the ability of JKB05 to colonize and reproduce will inevitably be reduced, thus reducing the control effect. Therefore, it is suggested that the bacteria be applied from the early growth stage after transplantation to prevent the disease.

\section{Discussion}

Traditional physical and chemical pesticides have not met the needs of disease prevention, and the identification of new technology and alternatives is urgently needed. Bio- control is the most ecofriendly approach to the management of plant disease (Sundaramoorthy et al., 2013). Some scientists have begun to conduct research on the enhancement and improvement of biocontrol bacteria. A level of treatment comparable to that of pesticides can be achieved by inoculation with two types of biocontrol bacteria $B$. subtilis GLB191 and Bacillus pumilus GLB197 (Wang et al., 2020). Vázquez-Figueroa et al. (2007) increased the thermostability of a thermostable glucose dehydrogenase from $B$. subtilis by introducing two point mutations while retaining its high specific activity. To improve the performance of strains and promote industrial microbial fermentation, there have been studies on the improvement of microorganisms using molecular genetics (Peano et al., 2012). B. thuringiensis is a well-known biopesticide that has been used for more than 80 years (Gillis et al., 2018). Park et al. (2017) developed advanced simulated strains of B. thuringiensis (Spo0A knockout and the deletion of two major small acid-soluble spore protein genes for en- 
vironmental friendliness and human safety) for outdoor environmental research. The stability of toxin protein was improved, and the residual period was prolonged after the toxin protein was adsorbed on the nano colloid (Vettori et al., 2000). A large number of Bacillus strains with strong antagonistic activity against plant pathogens have been identified in laboratory studies. Considerable research has been performed on the genes in Bacillus (Hoffmaster et al., 2004), and their synergistic effect has been studied to some extent. However, research on the preparation of synergetic Bacillus and the determination of its control effect remain rare.

The use of NPs as unconventional pesticides constitutes a new approach to combat pests that have become resistant to conventional chemical pesticides (El-Naggar et al., 2020). The application of nanotechnology to pesticides is in the initial stage. It lags far behind the progress in research in medicine, industry, materials and other fields. Nanotechnology is a new interdisciplinary subject that is expected to become the most important technology in the 21st century (Bogdan et al., 2015) and will certainly have a profound impact on the development of new pesticide formulations. In addition, the NPs release metal ions, which can provide trace elements for plants and enhance their disease resistance and growth. Trace elements, such as $\mathrm{Cu}, \mathrm{Fe}, \mathrm{Si}$, and $\mathrm{Zn}$, play an important role in the plant defense system by activating their defenses to prevent disease and effectively controlling the occurrence and development of the disease by stopping the invasion of pathogens (Ruttkay-Nedecky et al., 2017). In conclusion, the modified nano microbial complex was developed into a wettable powder, which exhibited effectively controlled the brown leaf spot disease caused by $N$. guilinensis on $P$. chinense. In this experiment, we found and confirmed that $\mathrm{SiO}_{2}(99.5 \%$ metal basis, 30 $\mathrm{nm}$ ) could inhibit the growth of the $N$. guilinensis and help $B$. megaterium JKB05 to resist the influence of adverse environments to some extent. Future research is merited to determine the mechanism of nanomaterials on Bacillus. The innovation of this experiment involves the application of nanotechnology to biological control in the field of forest pathology. Combining the advantages of nanomaterials with the advantages of biopesticides represents the main research direction of pesticides with good biocompatibility and environmental friendliness in the future, demonstrating strong value in research and prospects for application.

\section{Conflicts of Interest}

No potential conflict of interest relevant to this article was reported.

\section{Acknowledgments}

This research was supported by the National Natural Science Foundation of China (grant number 31700568) and the Science and Technology Innovation (Seedling Project) Cultivation Project of Sichuan (grant number 2021066).

\section{Electronic Supplementary Material}

Supplementary materials are available at The Plant Pathology Journal website (http://www.ppjonline.org/).

\section{References}

Ali, M. A., Ahmed, T., Wu, W., Hossain, A., Hafeez, R., Islam Masum, M. M., Wang, Y., An, Q., Sun, G. and Li, B. 2020. Advancements in plant and microbe-based synthesis of metallic nanoparticles and their antimicrobial activity against plant pathogens. Nanomaterials (Basel) 10:1146.

Azam, A., Ahmed, A. S., Oves, M., Khan, M. S. and Memic, A. 2012. Size-dependent antimicrobial properties of $\mathrm{CuO}$ nanoparticles against Gram-positive and -negative bacterial strains. Int. J. Nanomedicine 7:3527-3535.

Bacon, C. W., Yates, I. E., Hinton, D. M. and Meredith, F. 2001. Biological control of Fusarium moniliforme in maize. Environ. Health Perspect. 109 Suppl 2:325-332.

Bogdan, J., Jackowska-Tracz, A., Zarzyńska, J. and PławińskaCzarnak, J. 2015. Chances and limitations of nanosized titanium dioxide practical application in view of its physicochemical properties. Nanoscale Res. Lett. 10:57.

Boukaew, S., Prasertsan, P., Troulet, C. and Bardin, M. 2017. Biological control of tomato gray mold caused by Botrytis cinerea by using Streptomyces spp. BioControl 62:793-803.

Brader, G., Compant, S., Vescio, K., Mitter, B., Trognitz, F., Ma, L.-J. and Sessitsch, A. 2017. Ecology and genomic insights into plant-pathogenic and plant-nonpathogenic endophytes. Annu. Rev. Phytopathol. 55:61-83.

Bryaskova, R., Pencheva, D., Nikolov, S. and Kantardjiev, T. 2011. Synthesis and comparative study on the antimicrobial activity of hybrid materials based on silver nanoparticles (AgNps) stabilized by polyvinylpyrrolidone (PVP). J. Chem. Biol. 4:185-191.

Camara, M. C., Campos, E. V. R., Monteiro, R. A., do Espirito Santo Pereira, A., de Freitas Proença, P. L. and Fraceto, L. F. 2019. Development of stimuli-responsive nano-based pesticides: emerging opportunities for agriculture. J. Nanobiotechnology 17:100.

Chen, Y., Lu, W., Guo, Y., Zhu, Y. and Song, Y. 2019. Electrospun gelatin fibers surface loaded $\mathrm{ZnO}$ particles as a potential biodegradable antibacterial wound dressing. Nanomaterials 
(Basel) 9:525.

Chun, J. and Bae, K. S. 2000. Phylogenetic analysis of Bacillus subtilis and related taxa based on partial gyrA gene sequences. Antonie van Leeuwenhoek 78:123-127.

Claus, D. 1992. A standardized Gram staining procedure. World J. Microbiol. Biotechnol. 1992;8:451-452.

Collaborative International Pesticides Analytical Council. 1970a. MT 75 - Determination of $\mathrm{pH}$ values (revised method). URL https://cipac.org/index.php/d7 [8 February 2021].

Collaborative International Pesticides Analytical Council. 1970b. MT 15 - Suspensibility of wettable powders in water. URL https://www.cipac.org/index.php/mt-15-suspensibility-ofwettable-powders-in-water [8 February 2021].

Collaborative International Pesticides Analytical Council. 1970c. MT 17 loss in weight. URL https://www.cipac.org/index.php/ 12 [8 February 2021].

Collaborative International Pesticides Analytical Council. 1970d. MT 46.3 - Accelerated storage procedure. URL https:// www.cipac.org/index.php/mt-46-3-accelerated-storageprocedure/562-mt-46-3-accelerated-storage-procedure [8 February 2021].

Collaborative International Pesticides Analytical Council. 1970e. MT 53 - Wettability. URL https://www.cipac.org/index.php/ e15/544-mt-53-wettability [8 February 2021].

Collaborative International Pesticides Analytical Council. 1970f. MT 59 Sieve analysis. Collaborative International Pesticides Analytical Council. 2016f. MT 59 - Sieve analysis. URL https://www.cipac.org/index.php/s6/477-mt-59-sieve-analysis [8 February 2021].

Crijns, A. P. G., Gerbens, F., Plantinga, A. E. D., Meersma, G. J., de Jong, S., Hofstra, R. M. W., de Vries, E. G. E., van der Zee, A. G., de Bock, G. H. and te Meerman, G. J. 2006. A biological question and a balanced (orthogonal) design: the ingredients to efficiently analyze two-color microarrays with Confirmatory Factor Analysis. BMC Genomics 7:232.

Cromwick, A.-M. and Gross, R. A. 1995. Investigation by NMR of metabolic routes to bacterial $\gamma$-poly(glutamic acid) using ${ }^{13} \mathrm{C}$-labeled citrate and glutamate as media carbon sources. Can. J. Microbiol. 41:902-909.

de Campos, V. E. B., Ricci-Júnior, E. and Mansur, C. R. E. 2012. Nanoemulsions as delivery systems for lipophilic drugs. $J$. Nanosci. Nanotechnol. 12:2881-2890.

El-Naggar, M. E., Abdelsalam, N. R., Fouda, M. M. G., Mackled, M. I., Al-Jaddadi, M. A. M., Ali, H. M., Siddiqui, M. H. and Kandil, E. E. 2020. Soil application of nano silica on maize yield and its insecticidal activity against some stored insects after the post-harvest. Nanomaterials (Basel) 10:739.

Flanagan, J. L., Brodie, E. L., Weng, L., Lynch, S. V., Garcia, O., Brown, R., Hugenholtz, P., DeSantis, T. Z., Andersen, G. L., Wiener-Kronish, J. P. and Bristow, J. 2007. Loss of bacterial diversity during antibiotic treatment of intubated patients colonized with Pseudomonas aeruginosa. J. Clin. Microbiol. 45:1954-1962.

Gangireddygari, V. S. R., Kalva, P. K., Ntushelo, K., Bangep- pagari, M., Djami Tchatchou, A. D. and Bontha, R. R. 2017. Influence of environmental factors on biodegradation of quinalphos by Bacillus thuringiensis. Environ. Sci. Eur. 29:11. Gibreel, A., Sandercock, J. R., Lan, J., Goonewardene, L. A., Zijlstra, R. T., Curtis, J. M. and Bressler, D. C. 2009. Fermentation of barley by using Saccharomyces cerevisiae: examination of barley as a feedstock for bioethanol production and value-added products. Appl. Environ. Microbiol. 75:13631372.

Gillis, A., Fayad, N., Makart, L., Bolotin, A., Sorokin, A., Kallassy, M. and Mahillon, J. 2018. Role of plasmid plasticity and mobile genetic elements in the entomopathogen Bacillus thuringiensis serovar israelensis. FEMS Microbiol. Rev. 42:829-856.

Gray, K. M., Banada, P. P., O'Neal, E. and Bhunia, A. K. 2005. Rapid Ped-2E9 cell-based cytotoxicity analysis and genotyping of Bacillus species. J. Clin. Microbiol. 43:5865-5872.

He, L., Liu, Y., Mustapha, A. and Lin, M. 2011. Antifungal activity of zinc oxide nanoparticles against Botrytis cinerea and Penicillium expansum. Microbiol. Res. 166:207-215.

He, Y., Jin, Y., Wang, X., Yao, S., Li, Y., Wu, Q., Ma, G., Cui, F. and Liu, H. 2018. An antimicrobial peptide-loaded gelatin/ chitosan nanofibrous membrane fabricated by sequential layer-by-layer electrospinning and electrospraying techniques.. Nanomaterials (Basel) 8:327.

Hiradate, S., Yoshida, S., Sugie, H., Yada, H. and Fujii, Y. 2002. Mulberry anthracnose antagonists (iturins) produced by $\mathrm{Ba}$ cillus amyloliquefaciens RC-2. Phytochemistry 61:693-698.

Hoffmaster, A. R., Ravel, J., Rasko, D. A., Chapman, G. D., Chute, M. D., Marston, C. K., De, B. K., Sacchi, C. T., Fitzgerald, C., Mayer, L. W., Maiden, M. C., Priest, F. G., Barker, M., Jiang, L., Cer, R. Z., Rilstone, J., Peterson, S. N., Weyant, R. S., Galloway, D. R., Read, T. D., Popovic, T. and Fraser, C. M. 2004. Identification of anthrax toxin genes in a Bacillus cereus associated with an illness resembling inhalation anthrax. Proc. Natl. Acad. Sci. U. S. A. 101:8449-8454.

Hunter, P. 2009. Fight fire with fire. Can biopesticides fill the void left by banning chemical pesticides and herbicides? EMBO Rep. 10:433-436.

Johnson, F. H. and Campbell, D. H. 1945. The retardation of protein denaturation by hydrostatic pressure. J. Cell. Comp. Physiol. 26:43-46.

Khan, M. R., Ahamad, F. and Rizvi, T. F. 2019. Effect of nanoparticles on plant pathogens. In: Advances in phytonanotechnology: from synthesis to application, eds. by M. Ghorbanpour and S. H. Wani, pp. 215-240. Academic Press, London, UK.

Khan, M. R., Mohidin, F. A., Khan, U. and Ahamad, F. 2016. Native Pseudomonas spp. suppressed the root-knot nematode in in vitro and in vivo, and promoted the nodulation and grain yield in the field grown mungbean. Biol. Control 101:159168.

Khan, M. R. and Rizvi, T. F. 2014. Nanotechnology: scope and application in plant disease management. Plant Pathol. J. 13:214-231. 
Kim, S. W., Jung, J. H., Lamsal, K., Kim, Y. S., Min, J. S. and Lee, Y. S. 2012. Antifungal effects of silver nanoparticles (AgNPs) against various plant pathogenic fungi. Mycobiology 40:53-58.

Krieg, N. R., Ludwig, W., Whitman, W., Hedlund, B. P., Paster, B. J., Staley, J. T., Ward, N., Brown, D. and Parte, A. 2011. Bergey's manual of systematic bacteriology. Vol. 4. 2nd ed. Springer-Verlag, New York, NY, USA. 949 pp.

Lim, H. A. 2004. Nanotechnology in diagnostics and drug delivery. Med. Chem. Res. 13:401-413.

Liu, J., He, Y., Chen, S., Xiao, Y., Hu, M. and Zhong, G. 2014. Development of a freeze-dried fungal wettable powder preparation able to biodegrade chlorpyrifos on vegetables. PLoS ONE 9:e103558.

Liu, Y., Chen, Z., Ng, T. B., Zhang, J., Zhou, M., Song, F., Lu, F. and Liu, Y. 2007. Bacisubin, an antifungal protein with ribonuclease and hemagglutinating activities from Bacillus subtilis strain B-916. Peptides 28:553-559.

Mi, Y., Tan, W., Zhang, J., Wei, L., Chen, Y., Li, Q., Dong, F. and Guo, Z. 2018. Synthesis, characterization, and antifungal property of hydroxypropyltrimethyl ammonium chitosan halogenated acetates. Mar. Drugs 16:315.

Mondal, K. K. and Mani, C. 2012. Investigation of the antibacterial properties of nanocopper against Xanthomonas axonopodis pv. punicae, the incitant of pomegranate bacterial blight. Ann. Microbiol. 62:889-893.

Niu, D.-D., Liu, H.-X., Jiang, C.-H., Wang, Y.-P., Wang, Q.-Y., Jin, H.-L. and Guo, J.-H. 2011. The plant growth-promoting rhizobacterium Bacillus cereus AR156 induces systemic resistance in Arabidopsis thaliana by simultaneously activating salicylate- and jasmonate/ethylene-dependent signaling pathways. Mol. Plant-Microbe Interact. 24:533-542.

Oslizlo, A., Stefanic, P., Vatovec, S., Beigot Glaser, S., Rupnik, M. and Mandic-Mulec, I. 2015. Exploring ComQXPA quorumsensing diversity and biocontrol potential of Bacillus spp. isolates from tomato rhizoplane. Microb. Biotechnol. 8:527540.

Park, H.-J., Kim, S.-H., Kim, H.-J. and Choi, S.-H. 2006. A new composition of nanosized silica-silver for control of various plant diseases. Plant Pathol. J. 22:295-302.

Park, S., Kim, C., Lee, D., Song, D. H., Cheon, K. C., Lee, H. S., Kim, S. J., Kim, J. C. and Lee, S. Y. 2017. Construction of Bacillus thuringiensis simulant strains suitable for environmental release. Appl. Environ. Microbiol. 83:e00126-17.

Peano, C., Talà, A., Corti, G., Pasanisi, D., Durante, M., Mita, G., Bicciato, S., De Bellis, G. and Alifano, P. 2012. Comparative genomics and transcriptional profiles of Saccharopolyspora erythraea NRRL 2338 and a classically improved erythromycin over-producing strain. Microb. Cell Fact. 11:32.

Ruttkay-Nedecky, B., Krystofova, O., Nejdl, L. and Adam, V. 2017. Nanoparticles based on essential metals and their phytotoxicity. J. Nanobiotechnology 15:33.

Sekhon, B. S. 2014. Nanotechnology in agri-food production: an overview. Nanotechnol. Sci. Appl. 7:31-53.
Setlow, B., Atluri, S., Kitchel, R., Koziol-Dube, K. and Setlow, P. 2006. Role of dipicolinic acid in resistance and stability of spores of Bacillus subtilis with or without DNA-protective $\alpha / \beta$-type small acid-soluble proteins. J. Bacteriol. 188:37403747.

Shadduck, J. A. 1983. Some considerations on the safety evaluation of nonviral microbial pesticides. Bull. World Health Organ. 61:117-128.

Slama, H. B., Cherif-Silini, H., Chenari Bouket, A., Qader, M., Silini, A., Yahiaoui, B., Alenezi, F. N., Luptakova, L., Triki, M. A., Vallat, A., Oszako, T., Rateb, M. E. and Belbahri, L. 2019. Screening for Fusarium antagonistic bacteria from contrasting niches designated the endophyte Bacillus halotolerans as plant warden against Fusarium. Front. Microbiol. 9:3236.

Smibert, R. M. and Krieg, N. R. 1994. Phenotypic characterization. In: Methods for general and molecular bacteriology, eds. by P. Gerhardt, R. G. E. Murray, W. A. Wood and N. R. Krieg, pp. 611-654. American Society for Microbiology, Washington, DC, USA.

Storek, K. M., Chan, J., Vij, R., Chiang, N., Lin, Z., Bevers, J., 3rd, Koth, C. M., Vernes, J.-M., Meng, Y. G., Yin, J., Wallweber, H., Dalmas, O., Shriver, S., Tam, C., Schneider, K., Seshasayee, D., Nakamura, G., Smith, P. A., Payandeh, J., Koerber, J. T., Comps-Agrar, L. and Rutherford, S. T. 2019. Massive antibody discovery used to probe structure-function relationships of the essential outer membrane protein LptD. eLife 8:e46258.

Sundaramoorthy, S., Karthiba, L., Raguchander, T. and Samiyappan, R. 2013. Ecofriendly approaches of potential microbial bioagents in management of sheath rot disease in rice caused by Sarocladium oryzae (Sawada). Plant Pathol. J. (Faisalabad) 12:98-103.

Thomas, V., Herrera-Rimann, K., Blanc, D. S. and Greub, G. 2006. Biodiversity of amoebae and amoeba-resisting bacteria in a hospital water network. Appl. Environ. Microbiol. 72:2428-2438.

Van der Ent, S., Van Wees, S. C. M. and Pieterse, C. M. J. 2009. Jasmonate signaling in plant interactions with resistanceinducing beneficial microbes. Phytochemistry 70:1581-1588.

Vázquez-Figueroa, E., Chaparro-Riggers, J. and Bommarius, A. S. 2007. Development of a thermostable glucose dehydrogenase by a structure-guided consensus concept. Chembiochem 8:2295-2301.

Vettori, C., Gallori, E. and Stotzky, G. 2000. Clay minerals protect bacteriophage PBS1 of Bacillus subtilis against inactivation and loss of transducing ability by UV radiation. Can. J. Microbiol. 46:770-773.

Wang, H., Shan, W., Hu, H., Li, Y., Wang, Q., Wang, K. and Bian, F. 2020. Control effect of mixed inoculation of different biocontrol strains on Botrytis cinerea. Chin. J. Biol. Control 36:265-271 (in Chinese).

Yamamoto, S. and Harayama, S. 1995. PCR amplification and direct sequencing of $g y r B$ genes with universal primers and their application to the detection and taxonomic analysis 
of Pseudomonas putida strains. Appl. Environ. Microbiol. 61:1104-1109.

Zaki, O., Weekers, F., Thonart, P., Tesch, E., Kuenemann, P. and Jacques, P. 2020. Limiting factors of mycopesticide development. Biol. Control 144:104220.

Zeng, Y., Li, L., Zhu, T., Han, S. and Li, S. 2020. First report of brown leaf spot disease caused by Nigrospora guilinensis on Phellodendron chinense in China. Plant Dis. 104:2518.

Zeriouh, H., de Vicente, A., Pérez-García, A. and Romero, D. 2014. Surfactin triggers biofilm formation of Bacillus subtilis in melon phylloplane and contributes to the biocontrol activity. Environ. Microbiol. 16:2196-2211. 